\title{
Impact of Governance Structures on Environmental Disclosures in the Middle East and Africa*
}

\author{
Erhan Kilincarslan \\ University of Huddersfield \\ Department of Accounting, Finance and Economics \\ Queensgate, HD1 3DH \\ Huddersfield, UK \\ Email: e.kilincarslan@hud.ac.uk \\ Mohamed H. Elmagrhi \\ Swansea University \\ Department of Accounting and Finance \\ School of Management \\ Bay Campus, Skewen, SA1 8EN \\ Swansea, UK \\ Email: m.h.a.elmagrhi@swansea.ac.uk \\ Zezeng Li \\ University of Huddersfield \\ Department of Accounting, Finance and Economics \\ Queensgate, HD1 3DH \\ Huddersfield, UK \\ Email: z.li@hud.ac.uk
}

\section{Corresponding Author:}

Erhan Kilincarslan

This research did not receive any specific grant from funding agencies in the public, commercial, or not-for-profit sectors.

Declarations of interest: None

*Forthcoming in Corporate Governance: The International Journal of Business in Society - Accepted on 17 April 2020 


\title{
Impact of Governance Structures on Environmental Disclosures in the Middle East and Africa
}

\begin{abstract}
Purpose - This study investigates the impact of corporate governance structures on environmental disclosure practices in the Middle East and Africa.

Design/methodology/approach - The research model uses a panel dataset of 121 publicly listed (non-financial and non-utility) firms from 11 Middle East and African (MEA) countries over the period 2010-2017, employs alternative dependent variables and regression techniques, and is applied to various sub-groups to improve robustness.

Findings - The empirical results strongly indicate that MEA firms with high governance disclosures tend to have better environmental disclosure practices. The board characteristics of gender diversity, size, CEO/chairperson duality and audit committee size impact positively on MEA firms' voluntary environmental disclosures, whereas board independence has a negative influence.
\end{abstract}

Research limitations/implications - This study advances research on the relationship between corporate governance structures and environmental disclosure practices in MEA countries, but is limited to firms for which data are available from Bloomberg.

Practical implications - The results have important practical implications for MEA policymakers and regulators. Given the positive impact of board gender diversity on firms' environmental disclosures, policy reforms should aim to increase female directors. MEA corporations aiming to be more environmentally friendly should recruit females to top managerial positions.

Originality value - This is thought to be the first study to provide insights from the efficiency and legitimation perspectives of neo-institutional theory to explain the relationship between MEA firms' internal governance structures and environmental disclosures.

Keywords: Corporate governance structures; environmental disclosures; board characteristics; Middle East and Africa.

Paper type: Research paper 


\section{Introduction}

The Middle East and African (MEA) region has a rich array of natural resources. In 2017, it had $55 \%$ of the world's oil reserves (43\% of global production), $48 \%$ of gas reserves ( $24 \%$ of global production), and $1.4 \%$ of coal reserves (4.1\% of global production) (British Petroleum, 2018). These rich natural resources have increased the region's strategic importance, and have led to rapid economic transformation and development (Al-Rawashdeh et al., 2015). However, these major changes have raised serious concerns about environmental and public health in the MEA region. According to the World Health Organisation (WHO, 2016), air pollution is the main cause of various deadly illnesses (especially stroke and heart disease), and MEA countries are among the worst affected by air pollution, while the World Bank ranks seven MEA countries among the 20 experiencing the highest per capita $\mathrm{CO}_{2}$ emissions from energy consumption (World Bank, 2014). Nevertheless, positive actions have been taken by MEA countries to address these issues and improve environmental governance, management, policies and regulations. For example, South Africa's National Environmental Management Act, 2008 aimed to enhance environmental governance and management practices, and the Environmental Protection Agency in the United Arab Emirates (UAE) has launched a strategic plan to increase the use of renewable sources to $50 \%$ by 2050 (Official Portal of the UAE Government, 2018). MEA countries have also started to work closely with the US Environmental Protection Agency to improve "environmental governance, water pollution and water security, clean fuels and vehicles, public participation, and pollution prevention" (EPA, 2018). However, so far very little academic research on environmental governance and management has been conducted for the MEA region (Gerged et al., 2018). This study examines the impact of governance structures (composite governance index and board characteristics) on the environmental disclosures of publicly listed firms in the MEA region, using theoretical insights from the efficiency and legitimation perspectives of neo-institutional theory.

Previous studies (e.g. Gibson and O'Donovan, 2007; Walls et al., 2012; Haque and Ntim, 2018) suggest that corporations' institutional actors (e.g. governing board) and context may prompt them to voluntarily increase disclosures of environmental information. Neo-institutional theory (DiMaggio and Powell, 1983; Scott, 2001; Judge et al., 2010) predicts that social, political and economic institutional pressures may facilitate and/or restrain the diffusion of good environmental practices among corporations. Such pressures are driven by two key factors: efficiency and legitimation (Cormier et al., 2005; Ntim and Soobaroyen, 2013; Haque and Ntim, 2018). Neo-institutional theory has previously been employed in country-level analyses to explain institutional forces that may facilitate and/or restrain the implementation of good practices, including the adoption of good governance, corporate social responsibility (CSR) and international accounting practices (e.g. Chizema and Buck, 2006; Zattoni and Cuomo, 2008; Judge et al., 2010; Brammer et al., 2012; Ntim and Soobaroyen, 2013; Shahab and Ye, 2018). However, this theory has rarely been used to explain the main institutional drivers of the diffusion of good environmental practices at the corporate level.

Accordingly, this study employs and extends the neo-institutional theoretical perspective to explain the main drivers of voluntary environmental disclosures at the corporate level, focusing specifically on the theoretical implications of the legitimation and efficiency perspectives. The legitimation perspective suggests that normative, mimetic and coercive institutional pressures (i.e. pressures from legal mandates, group norms and stakeholders on which corporations 
depend) may force corporations to comply with good practices in order to meet the expectations of the wider community and legitimise their activities (Zattoni and Cuomo, 2008; Salama et al., 2011; Brammer et al., 2012) by committing to good environmental practices, including increased disclosure (Ntim and Soobaroyen, 2013; Deegan, 2014). Greater environmental disclosure may also improve corporate legitimacy by maintaining good relations with powerful stakeholders (trade unions, creditors/bondholders, students, government and employees) and winning their support (Hasseldine et al., 2005; Haque and Ntim, 2018).

Similarly, the efficiency perspective of neo-institutional theory indicates that institutional pressures may increase corporate competition for crucial resources to maintain sustainable operations and protect shareholders' interests (Toms, 2002; Zattoni and Cuomo, 2008). This view proposes that greater commitment to environmentally responsible activities/strategies in the form of improved environmental disclosures may improve corporations' operational efficiency by reducing related costs and increasing access to vital resources, such as business contracts and finance (Ntim and Soobaroyen, 2013). It may also improve corporate efficiency by minimising information asymmetry between different stakeholders (Jensen and Meckling, 1976; De Villiers et al., 2011). Given the complex nature and outcomes of environmental and governance practices (Parker, 2005; Ntim and Soobaroyen, 2013; Shahab and Ye, 2018), there is growing agreement that these practices need investigation, drawing on insights from both the legitimation and efficiency perspectives of neo-institutional theory (Zattoni and Cuomo, 2008; Filatotchev and Nakajima, 2014).

Empirical studies of voluntary environmental disclosures and their determinants are scarce (Wasiuzzaman and Mohammad, 2020) and have several weaknesses. First, despite empirical and theoretical suggestions that corporate decisions relating to disclosures, including environmental ones, are influenced mainly by the structure of top management teams (McGuinness et al., 2017), few studies examine the impact of board characteristics on environmental disclosure practices (Gibson and O'Donovan, 2007; Cong and Freedman, 2011; Walls et al., 2012; Haque and Ntim, 2018). Rather, existing studies tend to focus on the impact of board characteristics on firm value (Judge et al., 2003; Brown and Caylor, 2006; Bhagat and Bolton, 2008), executive pay (Hong and Minor, 2016; Ntim et al., 2017; Elmagrhi et al., 2018b), and governance, financial and social disclosures (Mallin, 2002; Haniffa and Cooke, 2005; Khan et al., 2013; Al-Bassam et al., 2018). Second, studies of environmental disclosure practices have been conducted largely in developed and emerging countries (McGuinness et al., 2017; Elmagrhi et al., 2018a), paying little attention to the MEA region (Akrout and Othman, 2013; Juhmani, 2014). However, the former tend to have different legal, political, regulative, cultural and economic systems from the latter (Ali et al., 2017), which may differently influence corporate disclosure behaviours. For example, Gerged et al. (2018) and Shahbaz et al. (2015) suggest that lack of regulatory enforcement in MEA countries may impact on their environmental disclosure practices. Third, the few extant studies of the MEA region are largely descriptive (Dawkins and Ngunjiri, 2008; Amran and Haniffa, 2011; Eljayash et al., 2012; Gerged et al., 2018), and focus on the effect of general corporate attributes (e.g. profitability and age) on voluntary environmental disclosure practices (Brammer and Pavelin, 2008; Ahmad et al., 2019). Furthermore, previous studies of the MEA region (Karim et al., 2006; Rizk et al., 2008; Habbash, 2016) examine the impact of only a small number of internal governance mechanisms on environmental disclosure practices, and no previous study appears to examine the impact of broader measures of governance quality using a composite index. 
Given these notable gaps in previous research, this study contributes to the literature in several ways. First, whereas previous environmental disclosure studies are largely descriptive/qualitative (Rizk et al., 2008; Habbash, 2016), this study offers seven-year longitudinal evidence on the extent and determinants of voluntary environmental disclosures by 121 firms from 11 MEA countries. Second, whereas most previous studies focus on the impact of general corporate attributes, this study offers new evidence on the extent to which internal governance structures influence the level of voluntary environmental disclosure practices by investigating the impact of several under-researched internal governance mechanisms. Finally, this study contributes new insights from the efficiency and legitimation perspectives of neo-institutional theory to better explain the impact of internal governance structures on environmental disclosure practices.

In the remainder of this paper, Section 2 presents the theoretical background, Section 3 reviews the empirical literature and develops the research hypotheses, Section 4 outlines the data and research design, Section 5 discusses the empirical results, and Section 6 draws some conclusions.

\section{Theoretical background}

This paper responds to a need to extend neo-institutional theory using more current explanations of power, interests and value perceptions to critically analyse organisational change and innovation (DiMaggio and Powell, 1983; Greenwood and Hinings, 1996; Scott, 2001; Damayanthi and Gooneratne, 2017). While conventional institutional theory emphasises inertia and path dependence, neo-institutional theory seeks to identify the determinants of organisational flexibility and change, reflecting a range of coercive and consensual strategies to achieve change across an organisational field (DiMaggio and Powell, 1983). However, full and uncontested institutionalisation is rare, and interests and power play a role in determining how organisations adapt to their institutional environments. For example, Oliver (1991) notes that because institutional environments are not always unitary and organisations are not always passive, organisations respond to institutional pressures according to their resource dependencies. Goodstein (1994) suggests that organisations respond strategically to institutional pressures, depending on their motivations, resource dependencies, idiosyncratic constraints and incentives. Thus, structural isomorphism has fundamental implications for profitable organisations, since it may signal effective and productive structures and processes with diffused best practices (Damayanthi and Gooneratne, 2017).

Although the neo-institutional theoretical framework has successfully been applied in previous country-level studies (Chizema and Buck, 2006; Zattoni and Cuomo, 2008; Judge et al., 2010; Brammer et al., 2012; Ntim and Soobaroyen, 2013; Shahab and Ye, 2018) to explain potential institutional drivers of corporate practices, including the adoption of good governance, CSR and international accounting practices, it has rarely been employed to explain the main institutional factors that facilitate and/or constrain the implementation of good environmental practices at the corporate level. This study employs the neo-institutional legitimation and efficiency perspectives to explain the impact of institutional actors (governing board characteristics) on the environmental disclosures of 121 listed companies in the MEA region.

From a legitimation perspective (DiMaggio and Powell, 1983; Suchman, 1995), organisations must not only aim to provide services/goods and maximise shareholders' wealth, but must also conform with the norms, values and expectations of broader society (Suchman, 1995). Failure 
to do so may threaten their legitimacy and survival (Ashforth and Gibbs, 1990). Neoinstitutional theory also proposes that organisations must demonstrate transparency and accountability to the wider community by incorporating socially expected and accepted norms, values and practices into their operations/activities (DiMaggio and Powell, 1983). Committing to good environmental practices through increased voluntary environmental disclosures may therefore improve corporate legitimacy by addressing broader societal concerns, and may help balance the conflicting informational needs of various stakeholders, and hence enhance corporate moral and rational legitimacy (Ntim and Soobaroyen, 2013). Overall, the legitimation perspective suggests that institutional actors, such as the governing board, may exert greater pressure on organisations to increase their environmental disclosures to conform with the norm, values and expectations of the wider community, and hence legitimise their organisational activities.

In addition to seeking legitimacy, another key organisational objective is to improve efficiency to maximise financial performance (Toms, 2002; Aguilera and Cuervo-Cazurra, 2004). The efficiency perspective of neo-institutional theory suggests that organisations comply with coercive, normative and mimetic pressures not only to improve their image/reputation, but also to gain competitive advantage, including securing access to crucial resources such as business contracts and finance (Pfeffer and Salancik, 1978; Toms, 2002). Committing to greater levels of environmental disclosure may improve corporate efficiency by meeting powerful stakeholders' expectations (e.g. providers of finance and resources) and obtaining their support to access crucial resources. Such commitment may also enhance corporate efficiency by minimising information asymmetry between stakeholders (Jensen and Meckling, 1976).

Therefore, given that previous studies (Ruigrok et al., 2006; De Villiers et al., 2011; McGuinness et al., 2017; Haque and Ntim, 2018) find that governance and board structures significantly influence corporate strategic decisions, including those relating to commitment to and disclosure of environmentally friendly activities, this study employs the neo-institutional legitimation and efficiency perspectives to explain the extent to which governance structure and governing board characteristics influence the voluntary environmental disclosures of 121 listed companies from the MEA region.

\section{Empirical literature and hypothesis development}

MEA countries have developed and transformed rapidly over recent years, mainly through oil, gas and coal production (Al-Rawashdeh et al., 2015), but at the expense of environmental and public health (World Bank, 2014; WHO, 2016). In response to these serious environmental and social threats, MEA countries have undertaken positive actions to improve environmental governance, management, policies and regulations. For example, South Africa issued new environmental protection laws and guidelines in 2008, and Egypt in 2009. However, lack of enforcement has led to poor implementation of these environmental reforms and measures (Shahbaz et al., 2015), so corporations may need to strengthen their internal governance structures, for example by appointing efficient corporate boards of appropriate size, diversity and independence.

\subsection{Corporate governance composite index and environmental disclosures}

The efficency perspective of neo-instutional theory suggests that complying with good governance polices and practices may mitigate agency problems and information asymmetry 
through increased monitoring of management activities (Jensen and Meckling, 1976), which may improve firms' environmental disclosures. According to this view, firms tend to comply with good governance practices to demonstrate accountability to powerful stakeholders and to access crucial resources (Haque and Ntim, 2018), which may impact positively on their environmental disclosure practices. In addition, the legitimation perspective indicates that complying with good governance practices not only improves corporate efficiency, but may also pressurise firms to enhance their environmental disclosures to improve their reputation and image in the marketplace (Cong and Freedman, 2011). Therefore, the environmental disclosures of well-governed firms (firms with high governance scores) are expected to be better than those of their poorly-governed counterparts.

Most previous empirical studies investigate the effect of corporate governance quality indices on firms' financial performance, and report that well-governed firms tend to perform better (e.g. Gompers et al., 2003; Brown and Caylor, 2006; Bebchuk et al., 2009). However, empirical research on the association between corporate governance quality indices and environmental disclosure practices is lacking. Cong and Freedman's (2011) study, the only one focusing on the US market, finds a positive relationship between a composite governance index and USlisted firms' environmental performance and disclosures. Hence, better-governed firms are expected to have better environmental disclosure practices than their poorly-governed counterparts in the MEA region.

Hypothesis 1: Corporate governance quality index and the environmental disclosure practices of MEA firms are positively associated.

\subsection{Board structure and environmental disclosures}

This study examines the impact of five board characteristics (size, diversity and independence, CEO duality and audit committee size) on environmental disclosure behaviours. These five variables were selected because extant literature suggests that they may impact significantly on firms' strategic decisions, including engagement in environmentally friendly activities (McGuinness et al., 2017; Haque and Ntim, 2018; Elmagrhi et al., 2018a). However, despite recognising the board of directors' important monitoring role over corporate strategic decisions, previous studies largely investigate the impact of general corporate features (e.g. profitability, size and age) on environmental disclosure practices (Karim et al., 2006; Brammer and Pavelin, 2008; Ahmad et al., 2019).

\subsubsection{Board gender diversity and voluntary environmental disclosures}

Previous studies suggest that corporate board diversity significantly influences leadership efficiency and effectiveness (McGuinness et al., 2017; Francoeur et al., 2019), using attributes such as gender, ethnicity, age, religion, experience and educational background (Erhardt et al., 2003; Ruigrok et al., 2007; Francoeur et al., 2019). This study focuses only on the impact of board gender on environmental disclosure behaviours, since data on other board diversity attributes are unavailable from Bloomberg. Theoretically, from a neo-institutional efficiency perspective, greater board gender diversity often enhances leadership efficiency and effectiveness by bringing diverse ideas, views, skills and experience into the boardroom, as well as improving board independence (Ruigrok et al., 2007; Prado-Lorenzo and GarciaSanchez, 2010). Similarly, the legitimation perspective indicates that greater gender diversity may enhance corporate reputation and image by broadening board discussions to incorporate 
the perspectives of powerful stakeholders (Torchia et al., 2011), thereby strengthening connections with these influential stakeholders and facilitating access to crucial resources. Therefore, based on both efficiency and legitimation perspectives, it is argued that board gender diversity may pressurise managers to engage in higher levels of voluntary environmental disclosure.

There is limited empirical evidence on the influence of board gender diversity on firms' environmental disclosure practices, rather than on firms' social responsibility disclosures (Williams et al., 2003; Barako and Brown, 2008; Zhang et al., 2013; Kyaw et al., 2017; Francoeur et al., 2019). Such studies have been conducted in the context of either developed (Prado-Lorenzo and Garcia-Sanchez, 2010; Ciocirlan and Pettersson, 2012; Glass et al., 2016; Ben-Amar et al., 2017) or emerging countries (Alazzani et al., 2017; McGuinness et al., 2017; Elmagrhi et al., 2018a). However, their findings suggest that board gender diversity has a positive influence on board independence and effectiveness, and that this may improve corporate environmental disclosure practices. No similar studies have been found relating to the MEA context. Therefore, it is hypothesised that:

Hypothesis 2: Board gender diversity and the environmental disclosure practices of MEA firms are positively associated.

\subsubsection{Board size and voluntary environmental disclosures}

From a neo-institutional legitimation perspective, larger governing boards may better connect organisations with their external environment, because they are associated with more diverse stakeholder representation, experience, expertise and skills, thereby helping to attract critical resources, including finance (Freeman and Reed, 1983; Reverte, 2009). Greater stakeholder diversity may increase pressure on corporations to enhance their voluntary environmental disclosures to meet societal expectations (Burke et al., 2019; Zou et al., 2019). In contrast, the neo-institutional efficiency perspective suggests that larger boards are often associated with poor governance owing to coordination and communication problems (Yermack, 1996), which may impact adversely on corporations' environmental disclosure practices. Therefore, corporations with larger boards may be less effective in protecting public interests, which may impact negatively on voluntary environmental disclosures.

Empirical studies of the impact of board size on firms' environmental disclosure behaviours in developed (Prado-Lorenzo and Garcia-Sanchez, 2010; De Villiers et al., 2011; Al-Shaer et al., 2015; Dixon-Fowler et al., 2017) and emerging markets (Zou et al., 2015, 2019) reveal a positive influence. However, no previous study has been found that examines this relationship with respect to the MEA region. It is therefore hypothesised that:

Hypothesis 3: Board size and the environmental disclosure practices of MEA firms are positively associated.

\subsubsection{Board independence and voluntary environmental disclosures}

The neo-institutional legitimation perspective suggests that outsider directors tend to have greater incentives for increased transparency and accountability to the wider community, largely because they often are more objective and independent from management than insider directors (Zahra and Stanton, 1988). This may impact positively on voluntary environmental disclosures. The legitimation view also proposes that outsider directors are often appointed to represent the demands and protect the interests of multiple stakeholders (Ibrahim and 
Angelidis, 1995), and consequently impose greater pressure on their organisations to increase their environmental disclosures to conform with the norms, values and expectations of the wider community, thereby legitimising their activities. In contrast, the neo-institutional efficiency view suggests that outsider directors are appointed primarily to represent and protect shareholders' interests; hence, when stakeholders' and shareholders' interests conflict, outsider directors are expected to endorse board decisions in shareholders' best interests, including those relating to disseminating more or less environmental information (Cramer and Hirschland, 2006). Therefore, outsider directors are less likely to act against board decisions, for example by revealing negative environmental information that might damage the company's reputation and image in the marketplace (Prado-Lorenzo and Garcia-Sanchez, 2010).

Previous empirical studies examine the impact of board independence on social (Zhang, 2012; Yekini et al., 2015; Jizi, 2017), financial (Chen and Jaggi, 2000) and general disclosure behaviours (Chahine and Filatotchev, 2008; Chau and Gray, 2010). Their findings suggest that the proportion of outsider directors relates positively to corporate voluntary disclosure practices. In contrast, Haniffa and Cooke (2005) report a negative and significant relationship between the proportion of outsider directors and social responsibility disclosures for 139 Malaysian listed firms. However, few studies consider the impact of board independence on voluntary environmental disclosure behaviours. Rao et al. (2012) report a positive influence of board size and board independence on the environmental reporting of 96 publicly-listed Australian firms, whereas Prado-Lorenzo and Garcia-Sanchez's (2010) sample of 283 firms listed on the FTSE Global Equity Index Series reveals a negative association between board independence and disclosure of greenhouse gas information. Based on the mixed evidence of previous theoretical and empirical literature, it is hypothesised that:

Hypothesis 4: Board independence and the environmental disclosure practices of MEA firms are positively associated.

\subsubsection{CEO duality and voluntary environmental disclosures}

The neo-institutional legitimation perspective suggests that dual leadership may reduce board independence and effectiveness by allowing CEOs to implement strategies that increase their personal benefits at the cost of stakeholders, and by diminishing the board's monitoring role over top management behaviour (Kim et al., 2009), thereby impacting negatively on voluntary environmental disclosures. In contrast, the efficiency perspective proposes that combining the chairperson and CEO roles may improve board efficiency by reducing the cost of communications among board members and speeding up decision-making processes (PradoLorenzo and Garcia-Sanchez, 2010). In addition, dual leadership may improve corporate competitive advantage and growth opportunities by providing better business networks through CEO knowledge, talent and experience (Samaha et al., 2015), which may impact positively on environmental disclosure practices.

Extensive empirical research on the impact of CEO duality, relating to general (Cheng and Courtenay, 2006; Li et al., 2008; Allegrini and Greco, 2013) and social disclosures (Haniffa and Cooke, 2002; Jizi et al., 2014), produces mixed findings. For example, Jizi et al. (2014) report a statistically positive relationship between CEO duality and CSR disclosure for the largest US commercial banks. In contrast, using a sample of 167 Malaysian listed firms, Haniffa and Cooke (2002) find no association between CEO duality and voluntary disclosure 
practices, and for 177 Italian listed firms, Allegrini and Greco (2013) report a negative link. There is limited evidence of the impact of CEO duality on environmental disclosures, and most previous studies examine only listed firms in developed and emerging economies. For example, Mallin et al. (2013) and Prado-Lorenzo and Garcia-Sanchez (2010) report a positive association between CEO duality and corporate environmental disclosure practices. Therefore, based on the findings of previous environmental disclosure studies, it is hypothesised that:

Hypothesis 5: CEO duality and the environmental disclosure practices of MEA firms are positively associated.

\subsubsection{Audit committee size and voluntary environmental disclosures}

Audit committees are considered to be an important internal governance mechanism for overseeing management actions, especially on issues relating to auditing, financial reporting, internal control and risk management (Raghunandan and Rama, 2003). Previous studies focus largely on the impact of audit committee characteristics, including presence, expertise, and frequency and size of meetings, on financial disclosure (Felo et al., 2003; Mangena and Pike, 2005; Allegrini and Greco, 2013) and auditing practices (Carcello and Neal, 2000, 2003). In contrast, few studies examine the impact on voluntary environmental disclosures of audit committee characteristics in general, and audit committee size in particular (Al-Shaer et al., 2015). However, given the importance of environmentally friendly activities and disclosures in managing corporate risk (Salama et al., 2011), which is the primary responsibility of audit committees (Al-Shaer et al., 2015; Yekini et al., 2015), audit committee characteristics are expected to influence corporate environmental disclosure practices. This study focuses mainly on the impact of audit committee size because data on this variable were available from Bloomberg for all sample firms. The neo-institutional legitimation perspective suggests that larger audit committees control and monitor managerial actions more effectively owing to greater expertise, skills and stakeholder representation (Chan and Li, 2008). This may increase pressure on corporations to make detailed disclosures of their environmentally friendly activities in order to legitimise their activities by fulfilling influential stakeholders' expectations. Similarly, the neo-institutional efficiency perspective indicates that increased stakeholder representation, which is often associated with larger audit committees, may enhance corporate efficiency by providing better connections with the external environment (e.g. influential stakeholders), and thus access to crucial resources (Harrison, 1987).

Much existing empirical literature examines the impact of audit committee size on firms' social responsibility disclosures (Abbott et al., 2004; Song and Windram, 2004; Jizi et al., 2014; Yekini et al., 2015), with mixed findings. For example, Persons (2009) reports that the level of voluntary ethics disclosure is positively linked to audit committee size. However, Yekini et al.'s (2015) sample of 73 UK-listed firms reveals a negative link between audit committee size and social responsibility disclosures, and Abbott et al. (2004) and Bedard et al. (2004) report an insignificant association between audit committee size and voluntary corporate disclosures. Few studies examine the impact of audit committee size on environmental disclosure practices. For example, using a sample of UK FTSE 350-listed firms, Al-Shaer et al. (2015) report a positive and significant association between audit committee characteristics, including size, and firms' environmental reputation. Therefore, it is hypothesised that:

Hypothesis 6: Audit committee size and the environmental disclosure practices of MEA firms are positively associated. 


\section{Research Methodology}

\subsection{Data and sample}

The Bloomberg database was used as a source for the research sample and data on the research variables in this study. Bloomberg's environmental score was used as an indicator of the extent of firms' environmental disclosures. Bloomberg assesses the amount of environmental data that firms report publicly by considering every data point disclosed (e.g. air quality, climate change, water \& energy management, and materials \& waste) and then calculating annual environmental disclosure scores ranging from 0.1 (minimum) to 100 (maximum). Accordingly, several criteria were applied in constructing the sample. First, all publicly listed firms in MEA countries were taken into account, but companies incorporated outside the MEA region were excluded. Second, financial institutions (e.g. banks, insurers, pension funds and investment trusts) and utilities (e.g. gas, electricity and water) were removed, since they tend to have different capital structures and governance, disclosure and listing requirements (Elshandidy et al., 2015; Elmagrhi et al., 2018a, 2018b), which may impact differently on environmental disclosures. Third, the sample was confined to firms for which environmental scores were available from Bloomberg. As a result of these selection criteria, the final sample consisted of 587 firm-year observations from 121 unique (non-financial and non-utility) firms over the period 2010-2017. This sample period was used because Bloomberg environmental scores were unavailable for the majority of MEA region firms before 2010, and the most recent available data were for fiscal year 2017.

Table 1 reports distributions of the firms by country, time and industry. The 121 firms were from 11 MEA countries: Botswana, Israel, Kenya, Mauritius, Nigeria, Oman, Qatar, Saudi Arabia, South Africa, UAE and Zambia (Panel A). However, numbers of unique firms ranged from one firm and four firm-year observations in Kenya, to 90 firms and 475 firm-year observations in South Africa. This is because the final sample was limited by the availability of environmental disclosure scores from the Bloomberg database. Furthermore, in order to alleviate any survivorship bias, the sample included companies that had been delisted (owing to business failure, mergers \& acquisitions, etc.) or were first listed during the sample period. Hence, the number of firms selected increased over time (see Panel B of Table 1). Panel C illustrates the broad distribution of MEA firms across eight industries, classified according to the Bloomberg Industry Classification System (BICS): communications (10.7\%), consumer discretionary $(16.2 \%)$, consumer staples $(21.8 \%)$, energy $(2.7 \%)$, healthcare $(6.5 \%)$, industrials $(11.8 \%)$, materials $(27.1 \%)$ and technology $(3.2 \%)$.

--Insert Table 1 about here--

\subsection{Research design, model and variables}

To test the research hypotheses, a mathematical model and a set of variables were formulated to capture the effects of internal governance variables on the environmental disclosure practices of publicly-listed firms in the MEA region. As previously explained, Bloomberg's environmental score was used as the dependent variable (E-SCORE) to measure firms' environmental disclosure practices. Test variables were then defined, representing each of the six hypotheses. Bloomberg's governance disclosure scores were employed as a proxy for firms' corporate governance quality index (G-SCORE). Bloomberg evaluates the amount of governance data that firms report publicly, and calculates annual scores ranging from 0.1 for 
firms revealing minimal governance information, to 100 for those disclosing every data point (board independence, structure \& tenure, compensation, diversity and shareholders' rights). To examine the impact of board characteristics on environmental disclosure practices, the proportion of female directors on the board (FEMDIR), board size (BSIZE), independent directors (BINDEP), CEO/chairperson duality (DUAL) and audit committee size (AUDIT) were used as independent variables. Consistent with previous studies (Hasseldine et al., 2005; Salama et al., 2012; Al-Shaer et al., 2015; Al-Najjar and Kilincarslan, 2016; Elmagrhi et al., 2016; Kiesewetter and Manthey, 2017; Bacha and Ajina, 2020), the study controlled for insider ownership (INSIDER), institutional ownership (INST), profitability (ROA), debt ratio (DEBT), growth (GROW), firm size (FSIZE) and firm age (AGE). Finally, as the final sample was drawn from 11 MEA countries, representing eight broad industries and covering a relatively long time period (2010-2017), an attempt was made to control for country- and industry-specific effects and unobserved time-varying factors by including country (COUNTRY), industry (INDUSTRY) and year (YEAR) dummies in the research model. Definitions of all variables used in the analysis are provided in Table 2.

--Insert Table 2 about here--

Accordingly, the main empirical model is specified as:

$$
\begin{aligned}
& \mathrm{E}-S C O R E_{i, k, t}=\alpha_{i}+\beta_{1} \mathrm{G}_{-} \mathrm{SCORE}_{i, k, t}+\beta_{2} \mathrm{FEMDIR}_{i, k, t}+\beta_{3} \mathrm{BSIZE}_{i, k, t}+\beta_{4} \mathrm{BINDEP}_{i, k, t}+ \\
& \beta_{5} \mathrm{DUAL}_{i, k, t}+\beta_{6} \mathrm{AUDIT}_{i, k, t}+\beta_{7} \mathrm{INSIDER}_{i, k, t}+\beta_{8} \mathrm{INST}_{i, k, t}+\beta_{9} \mathrm{ROA}_{i, k, t}+\beta_{10} \mathrm{DEBT}_{i, k, t}+ \\
& \beta_{11} \mathrm{GROW}_{i, k, t}+\beta_{12} \mathrm{FSIZE}_{i, k, t}+\beta_{13} \mathrm{AGE}_{i, k, t}+\sum_{k=1}^{M} \beta_{k} \mathrm{COUNTRY}_{i, t}+\sum_{j=1}^{N} \beta_{j} \mathrm{INDUSTRY}_{i, k, t} \\
& +\sum_{t=1}^{T} \beta_{t} \mathrm{YEAR}_{i, k}+\varepsilon_{i, k, t}
\end{aligned}
$$

where $i, k, t$ and $j$ denote firm, country, year and industry, respectively.

Although the sample covers 11 countries, the distribution of firms, and thus the number of firmyear observations across countries, is not homogenous, the number of unique firms from South Africa being significantly larger than from other countries, potentially biasing the findings. To eliminate the impact of sample distribution heterogeneity across countries, the empirical model was applied to the MEA panel dataset using weighted least squares (WLS) regression, with weights calculated as the value of unity divided by the number of firm-year observations per country.

\section{Empirical results and discussion}

\subsection{Descriptive statistics and univariate tests}

Panels A and B of Table 3 present descriptive statistics for the research variables across the 11 examined countries. These show that the mean (median) environmental disclosure score (ESCORE) of all firms in the sample is 26.22 (27.08), but means vary between countries from a minimum of 9.19 (Zambia) to a maximum of 30.23 (Qatar), while the lowest median score is 4.65 (Saudi Arabia) and the highest 27.91 (South Africa). These scores seem realistic and are consistent with those reported by Gerged et al. (2018). The mean corporate governance disclosure score (G-SCORE) ranges from 39.73 (Qatar) to 58.72 (South Africa), with an average (median) value of 56.72 (57.14) for all firms, in line with Elgammal et al.'s (2018) findings. 
The results reveal considerable differences in the mean and median values of each examined board characteristic variable across countries. For instance, the mean (median) for board independence (BINDEP) ranges from $0.219(0.188)$ for Nigerian firms to $1.00(1.00)$ for Omani firms, with a mean (median) of $0.573(0.6)$ for the entire sample. Thus, the proportion of independent directors on boards is on average $57 \%$ in the investigated MEA firms. The average board size (BSIZE) is 11 directors (varying from a median of 8.0 for Oman and the UAE, to 13.5 for Nigeria). Audit committees (AUDIT) generally comprise four directors (median of 4 for all firms). The proportion of female directors is, on average, only about 19\%, which suggests that the boards of public firms in the MEA region are male-dominated. The figures for DUAL reveal that the CEO is also the chairperson in only some firms in the UAE and South Africa, with an overall mean of $0.01(1 \%)$.

Panel B of Table 3 also provides information on firm-specific variables. The mean for institutional ownership (INST) of 0.549 exhibits a high ownership concentration, since institutional investors hold about 55\% of the outstanding shares of the sampled MEA firms. In contrast, the proportion of stock ownership by insiders (INSIDER) is around 1\% on average. Approximately $14 \%$ of the full sample of firms have debt financing (mean of 0.141 for DEBT) in their capital structure, with a $7 \%$ return on total assets invested (mean of 0.07 for ROA) between 2010 and 2017. The mean for growth opportunities (GROW) of 2.04 is twice as high as unity, suggesting that MEA firms had good investment prospects over the sample period. However, Table 3 also reveals differences between countries in the mean and median values of each ownership and financial characteristic.

Univariate analysis was conducted to compare countries based on each research variable (Panels A and B of Table 3). One-way ANOVA tests and non-parametric Kruskal-Wallis tests were used to determine whether differences between countries in the sample were statistically significant. Both parametric and non-parametric test results showed highly significant differences in environmental and governance disclosure scores, board, ownership and financial characteristics. However, this is unsurprising, given the 11 countries' differing institutional settings, political and economic systems, legal structures and cultural values.

--Insert Table 3 about here--

Table 4 reports the results of Pearson's correlation matrix and variance inflation factor (VIF) values for the independent variables to check for multicollinearity. Although the results illustrate some significant correlations between the research variables, there is no high correlation between any two of them, and a few are moderately correlated. For example, the highest Pearson's correlation figures for G-SCORE-INST, BINDEP-INST, BSIZE-FSIZE and ROA-GROW range from $30 \%$ to $45 \%$. The VIF statistics also suggest no multicollinearity between the independent variables, since no VIF exceeds the rule-of-thumb threshold of 10 . In fact, the VIF values are comparatively low, ranging from 1.04 to 1.42 .

--Insert Table 4 about here--

\subsection{Regression analyses and discussion}

Table 5 shows the results of regression estimates to test the research hypotheses on the impact of corporate governance mechanisms on MEA firms' environmental disclosure practices. Column 1 reports estimates for the full sample, Column 2 excludes South Africa, and Column 
3 shows the estimates only for South Africa. Columns 4 and 5 display results for Middle-East and African firms, respectively. The research model was computed on the full sample and four different sub-samples in order to provide more robust findings and assess the consistency of the main findings across different dimensions. More specifically, South Africa has considerably more firm-year observations than other countries; thus, the model was run for the sample excluding South Africa and for South Africa alone to ensure that the main results were not dictated by this country's data. In view of the countries' dissimilarities, the sample was also stratified into two groups - Middle-Eastern firms (Column 4) and African firms (Column 5) to check whether the findings differed significantly between these two regions. To control for potential sample distribution heterogeneity across countries and country groups, WLS regression was used (Columns 1, 2, 4 and 5), but pooled ordinary least squares (OLS) regression was performed in the single-country model for South Africa (Column 3). WLS and OLS estimations were computed using White's corrected heteroscedasticity-robust regressions for all specifications.

\section{--Insert Table 5 about here--}

At first glance, the results show that the $F$-statistics for each of the five regressions are statistically significant at the $1 \%$ level, indicating the overall significance of the research model for the full sample and the sub-samples. The $R^{2}$ values of estimated regression equations vary from around $52 \%$ to $79 \%$, suggesting the research model's good prediction power (goodness of fit).

Column 1 of Table 5 reveals a positive and highly significant coefficient for G-SCORE $\left(\beta_{1}=\right.$ 0.673, $p<0.01$ ) for all MEA firms, which holds even after excluding South Africa from the regression (Column 2; $\beta_{1}=0.465, p<0.01$ ). Indeed, the coefficients of this variable are positive and statistically significant for all sub-samples (South Africa $\beta_{1}=0.536, p<0.01$; Middle East $\beta_{1}=0.500, p<0.05$; Africa $\beta_{1}=0.288, p<0.01$ ). This finding extends the limited existing evidence to the MEA region and shows that the corporate governance index score has a positive effect on MEA firms' environmental disclosure practices. This is consistent with Cong and Freedman's (2011) study and with the neo-institutional legitimation and efficiency perspectives, in that complying with good governance practices may increase pressure on firms to engage in environmentally friendly activities to demonstrate public accountability, enhance their reputation/image and win the support of powerful shareholders (Haque and Ntim, 2018). Therefore, the empirical results support Hypothesis 1.

The results also reveal a strong and positive association between board gender diversity (FEMDIR) and environmental disclosure practices. The coefficients of FEMDIR are positive and statistically significant for the full sample $\left(\beta_{2}=0.251, p<0.01\right)$ and for all sub-samples (non-South Africa $\beta_{2}=0.486, p<0.01$; only South Africa $\beta_{2}=0.125, p<0.05$; Middle East $\beta_{2}$ $=0.416, p<0.10$; Africa $\beta_{2}=0.230, p<0.01$ ). This is consistent with the findings of Elmagrhi et al. (2018a) and McGuinness et al. (2017) in China, and with several studies of developed markets (e.g. Prado-Lorenzo and Garcia-Sanchez, 2010; Ciocirlan and Pettersson, 2012; Glass et al., 2016; Ben-Amar et al., 2017). From the neo-institutional efficiency and legitimation perspectives, board gender diversity may improve board effectiveness through diverse ideas, views, skills and experience (Ruigrok et al., 2007; Prado-Lorenzo and Garcia-Sanchez, 2010), and may enhance corporate reputation/image by providing better connections with powerful stakeholders (Torchia et al., 2011). This may in turn increase managerial monitoring and 
encourage firms to engage in greater levels of voluntary environmental disclosure (Elmagrhi et al., 2018a). Accordingly, the findings for MEA firms support Hypothesis 2.

Column 3 of Table 1 reveals a positive effect of board size (BSIZE) on the environmental disclosure practices of South African firms, with a positive and statistically significant coefficient for this variable $\left(\beta_{3}=0.554, p<0.05\right)$. However, the coefficients of BSIZE in Columns 1, 2, 4 and 5 are not significant, suggesting that board size has no influence on environmental disclosure for the full, non-South Africa, Middle East and Africa samples. This suggests that board size is important in helping increase the environmental disclosure practices only of South African firms. It also indicates that although South Africa has the largest number of firm-year observations in the sample, it does not dominate the estimates. The positive impact of board size on South African companies' environmental disclosures is consistent with previous studies (e.g. Prado-Lorenzo and Garcia-Sanchez, 2010; De Villiers et al., 2011; Dixon-Fowler et al., 2017; Zou et al., 2015, 2019) and the legitimation perspective of neoinstitutional theory, in that larger boards encourage companies to engage more in voluntary environmental disclosures to satisfy the expectations of wider society, which in turn helps improve corporations' legitimacy and image by maintaining good relations with powerful stakeholders. However, owing to the non-significant association for firms from the other 10 countries, the results only partially support Hypothesis 3 .

In contrast, the regression estimates show a significant negative impact of board independence (BINDEP) on MEA firms' environmental disclosure practices. The coefficients of BINDEP are negative and highly significant for all firms $\left(\beta_{4}=-0.136, p<0.01\right)$ and for the sample excluding South Africa (Column 2; $\beta_{4}=-0.305, p<0.01$ ). The negative impact also holds across the sub-samples (South Africa $\beta_{4}=-0.080, p<0.05$; Middle East $\beta_{4}=-0.429, p<0.01$; Africa $\left.\beta_{4}=-0.079, p<0.10\right)$. This inverse relationship may arise from independent directors being appointed for symbolic reasons (i.e. to meet the expectations of powerful stakeholders and wider society), making them less motivated to monitor managerial activities (Lambert et al., 1993), and negatively affecting firms' environmental disclosures. In this respect, the empirical evidence is consistent with Prado-Lorenzo and Garcia-Sanchez's (2010) findings and suggests that board independence is negatively associated with firms' disclosures of environmentally friendly activities in the MEA region. Hence, Hypothesis 4 is rejected.

The regression results also show a positive impact of CEO/chairperson duality (DUAL) on environmental disclosure practices for the full sample $\left(\beta_{5}=9.681, p<0.05\right)$, but its effect varies across the sub-samples. The coefficients of DUAL are not significant for the Africa and South Africa sub-samples, but statistically significant for Middle Eastern firms $\left(\beta_{5}=19.381, p<\right.$ 0.05). The results contradict the neo-institutional legitimation view that dual leadership may reduce board independence and effectiveness, but are consistent with the efficiency view that combining the two roles may improve board efficiency (e.g. improving communications, speeding up decision making), which in turn positively affects environmental disclosure practices. Mallin et al. (2013) and Prado-Lorenzo and Garcia-Sanchez (2010) also report a positive relationship between CEO duality and firms' disclosures of environmental practices. However, since this positive impact is not consistent across all MEA countries in the sample, the results only partially support Hypothesis 5 .

The coefficient of AUDIT in Column 1 is insignificant, which implies that audit committee size has no impact on MEA firms' environmental disclosures. Nevertheless, this variable has statistical significance in some sub-samples: it is statistically significant and positive for non- 
South Africa $\left(\beta_{6}=3.643, p<0.05\right)$, Middle East $\left(\beta_{6}=5.553, p<0.05\right)$ and Africa $\left(\beta_{6}=1.120\right.$, $p<0.10)$, but not significant for South African firms. This suggests that audit committees are an important governance mechanism for improving MEA firms' environmental disclosure practices. This positive impact is contrary to Abbott et al.'s (2004) and Bedard et al.'s (2004) reports of an insignificant association, and Yekini et al.'s (2015) reported negative link between audit committees and various corporate voluntary disclosures. Rather, there is a positive relationship between audit committee size and MEA firms' environmental disclosure practices, apart from for South African firms, consistent with the legitimation and efficiency perspectives of neo-institutional theory and Al-Shaer et al.'s (2015) findings. Therefore, the results partially support Hypothesis 6.

Finally, the results in Table 5 show that, apart from firm growth (GROW), the control variables (ownership and financial characteristics) have significant effects on MEA corporations' environmental disclosure practices. Profitability (ROA) and debt level (DEBT) have a consistently negative impact, whereas firm size (FSIZE) and firm age (AGE) have strong positive effects on environmental disclosure practices across all MEA firms and countries. On the other hand, both ownership structure variables - insider (INSIDER) and institutional (INST) stock-holdings - exhibit a negative influence. However, this negative association does not hold for all MEA firms in the sample, but differs across countries/country groups.

\subsection{Additional analyses}

This sub-section presents the results of sensitivity tests to check the robustness of the main findings. First, endogeneity may occur for two reasons: reverse causality, and correlation of the independent variables with the error term. In order to check whether endogeneity may have complicated the specified models, the previous regression tests were replicated using one-year lagged values for all independent (test and control) variables, except for country, industry and year dummies. Using the lagged values alleviates reverse causality bias, as the current dependent variable cannot affect any of the lagged independent variables, and helps prevent correlation between the error term and the independent variables, since the lagged values cannot be correlated with the current-year error term even if they are highly correlated with current values of the independent variables. Accordingly, Table 6 reports regression estimates using the one-year lagged values of independent variables for the full sample and four subsamples. The results are very similar to those reported in Table 5, indicating that the previous findings do not suffer from endogeneity, and thus confirming the robustness of the main results.

--Insert Table 6 about here--

Second, an alternative econometric regression technique was used to determine whether the above results also held or were sensitive to the use of a different dependent variable. This was used to estimate the probability of having a higher environmental disclosure score, since the distribution of this variable varied substantially among firms and across countries (see Table 3 ). Hence, a binary dependent variable (denoted as E-CODE) was created, equalling 1 if the firm's environmental score was greater than the mean E-SCORE of $26.22 \%$ (high environmental disclosure) and 0 otherwise (low environmental disclosure). Next, the corresponding probit regression models were formulated as an appropriate econometric technique for estimating binary dependent variables $(0 / 1)$. Table 7 presents the results of the probit estimates for the full, non-South Africa, South Africa, Middle East and Africa samples 
(Columns 1 to 5). These show that all probit coefficients for the probability of having a high environmental disclosure score (E-CODE) are in line with estimates reported in Table 5. These results are consistent because the test variables have the same directional signs and similar statistical significance, further supporting the robustness of the main findings.

--Insert Table 7 about here--

\section{Conclusions}

This paper investigates the extent to which internal governance structures influenced the environmental disclosure practices of 121 MEA firms over the period 2010-2017. It contributes new evidence from 11 MEA countries, and thus extends the limited studies previously conducted in this region. Unlike previous research, which focuses mainly on the effects of a small number of internal governance mechanisms on environmental disclosure practices, this study considers the impact of various, largely unexamined internal governance mechanisms on firms' environmental disclosure practices, and hence presents empirical results from a more comprehensive model. The study also offers new insights into the relationship of interest by integrating the efficiency and legitimation perspectives of neo-institutional theory.

Several important conclusions can be drawn from the findings. First, the empirical results provide strong evidence that MEA corporations complying with good governance practices tend to have better environmental disclosure practices than their poorly-governed counterparts. Second, the findings indicate that MEA firms' board characteristics generally have significant effects on their environmental disclosure practices, with positive and significant associations between board gender diversity, board size, $\mathrm{CEO}$ /chairperson duality, audit committee size and voluntary environmental disclosures, although board independence is negatively associated. Overall, these findings support the efficiency and legitimation predictions of neo-institutional theory.

The results have various practical implications for MEA firms and regulatory and enforcement bodies. They reveal that environmental disclosure scores are generally low, but vary significantly among firms in the MEA region. This may prompt MEA regulators and policymakers to find ways to improve environmental compliance/disclosure practices. They might consider establishing independent committees to monitor MEA firms' implementation and disclosure of environmental practices. Internal governance structures are positively and significantly associated with environmental disclosure practices, implying that governance and environmental reforms should be developed jointly to improve effectiveness. In addition, MEA firms with more female directors on their boards tend to have better environmental disclosure scores, which may motivate regulators to develop new legislation forcing firms to increase the proportion of female directors in their boardrooms to strengthen environmental practices. Finally, board independence has a significant negative relationship with environmental disclosure scores, which may encourage MEA firms to re-evaluate the adverse effect of independent directors on their environmentally friendly activities.

Although the findings do not suffer from endogeneity and hold when using alternative environmental disclosure measures, the study has limitations. First, the sample only covered MEA firms for which environmental disclosure data were available from Bloomberg. This limitation resulted in significant differences in the distribution of firms, and thus the number of firm-year observations across countries. Hence, further research might extend this analysis 
by incorporating more MEA firms once data become available. Second, as the empirical results are only for MEA firms, future studies might explore the effect of internal governance structures on environmental disclosure practices in other developing and emerging countries. Third, the quantitative approach employed in this research may not provide in-depth insights into the drivers of voluntary environmental disclosure practices. Therefore, future research might extend this analysis through a qualitative approach (e.g. case studies and interviews) to improve understanding of the extent and determinants of voluntary environmental disclosure practices. This study provides a valuable benchmark for such future research. 


\section{References}

Abbott, L.J., Parker, S. and Peters, G.F. (2004), "Audit committee characteristics and restatements", Auditing: A Journal of Practice and Theory, Vol. 23 No. 1, pp. 69-87.

Aguilera, R.V. and Cuervo-Cazurra, A. (2004), "Codes of good governance worldwide: what is the trigger?", Organization Studies, Vol. 25 No. 3, pp. 415-443.

Ahmad, N., Li, H.Z. and Tian, X.L. (2019), "Increased firm profitability under a nationwide environmental information disclosure program? Evidence from China", Journal of Cleaner Production, Vol. 230, pp. 1176-1187.

Akrout, M.M. and Othman, H.B. (2013), "A study of the determinants of corporate environmental disclosure in MENA emerging markets", Journal of Reviews on Global Economics, Vol. 2, pp. 46-59.

Alazzani, A., Hassanein, A. and Aljanadi, Y. (2017), "Impact of gender diversity on social and environmental performance: evidence from Malaysia", Corporate Governance: The International Journal of Business in Society, Vol. 17 No. 2, pp. 266-283.

Allegrini, M. and Greco, G. (2013), "Corporate boards, audit committees and voluntary disclosure: evidence from Italian listed companies", Journal of Management and Governance, Vol. 17 No. 1, pp. 187-216.

Al-Bassam, W.M., Ntim, C.G., Opong, K.K. and Downs, Y. (2018), "Corporate boards and ownership structure as antecedents of corporate governance disclosure in Saudi Arabian publicly listed corporations", Business and Society, Vol. 57 No. 2, pp. 335-377.

Al-Najjar, B. and Kilincarslan, E. (2016), "The effect of ownership structure on dividend policy: evidence from Turkey", Corporate Governance: The International Journal of Business in Society, Vol. 16 No. 1, pp. 135-161.

Ali, W., Frynas, J.G. and Mahmood, Z. (2017), "Determinants of corporate social responsibility (CSR) disclosure in developed and developing countries: a literature review", Corporate Social Responsibility and Environmental Management, Vol. 24 No. 4, pp. 273-294.

Al-Rawashdeh, R., Jaradat, A.Q. and Al-Shboul, M. (2015), "Air pollution and economic growth in MENA countries: testing EKC hypothesis", Environmental Research, Engineering and Management, Vol. 70 No. 4, pp. 54-65.

Al-Shaer, H., Salama, A. and Toms, S. (2015), "The impact of corporate environmental disclosures and audit committees on environmental reputation", available at: SSRN: https://ssrn.com/abstract $=2629763$

Amran, A. and Haniffa, R. (2011), "Evidence in development of sustainability reporting: a case of a developing country", Business Strategy and the Environment, Vol. 20 No. 3, pp. 141-156.

Ashforth, B.E. and Gibbs, B.W. (1990), "The double-edge of organizational legitimation", Organization Science, Vol. 1 No. 2, pp. 177-194.

Bacha, S. and Ajina, A. (2020), "CSR performance and annual report readability: evidence from France", Corporate Governance: The International Journal of Business in Society, Vol. 20 No. 2, pp. 201-215. 
Barako, D. and Brown, A. (2008), "Corporate social reporting and board representation: evidence from the Kenyan banking sector", Journal of Management and Governance, Vol. 12 No. 4, pp. 309-324.

Bebchuk, L., Cohen, A. and Ferrell, A. (2009), "What matters in corporate governance?", Review of Financial Studies, Vol. 22 No. 2, pp. 783-827.

Bedard, J., Chtourou, S.M. and Courteau, L. (2004), "The effect of audit committee expertise, independence, and activity on aggressive earnings management", Auditing: A Journal of Practice and Theory, Vol. 23 No. 2, pp. 13-35.

Ben-Amar, W., Chang, M. and McIlkenny, P. (2017), "Board gender diversity and corporate response to sustainability initiatives: evidence from the Carbon Disclosure Project", Journal of Business Ethics, Vol. 142, pp. 369-383.

Berrone, P., Cruz, C., Gomez-Mejia, L.R. and Larraza-Kintana, M. (2010), "Socioemotional wealth and corporate responses to institutional pressures: do family-controlled firms pollute less?", Administrative Science Quarterly, Vol. 55 No. 1, pp. 82-113.

Brammer, S., Jackson, G. and Matten, D. (2012), "Corporate social responsibility and institutional theory: new perspectives on private governance", Socio-Economic Review, Vol. 10 No. 1, pp. 3-28.

Brammer, S. and Pavelin, S. (2008), "Factors influencing the quality of corporate environmental disclosure", Business Strategy and the Environment, Vol. 17 No. 2, pp. 120136.

Brown, L.D. and Caylor, M.L. (2006), "Corporate governance and firm valuation", Journal of Accounting and Public Policy, Vol. 25 No. 4, pp. 409-434.

Bhagat, S. and Bolton, B. (2008), "Corporate governance and firm performance", Journal of Corporate Finance, Vol. 14 No. 3, pp. 257-273.

British Petroleum. (2018), "BP statistical review of world energy 2018”, June 2018, available at: $\quad$ https://www.bp.com/content/dam/bp/business-sites/en/global/corporate/pdfs/energyeconomics/statistical-review/bp-stats-review-2018-full-report.pdf (accessed 2 March 2019).

Burke, J.J., Hoitash, R. and Hoitash, U. (2019), "The heterogeneity of board-level sustainability committees and corporate social performance", Journal of Business Ethics, Vol. 154 No. 4, pp. $1161-1186$.

Carcello, J.V. and Neal, T.L. (2003), "Audit committee characteristics and auditor dismissals following "new” going-concern reports", Accounting Review, Vol. 78 No. 1, pp. 95-117.

Carcello, J.V. and Neal, T.L. (2000), "Audit committee composition and auditor reporting", Accounting Review, Vol. 75 No. 4, pp. 453-467.

Chahine, S. and Filatotchev, I. (2008), "The effects of information disclosure and board independence on IPO discount", Journal of Small Business Management, Vol. 46 No. 2, pp. 219-241.

Chan, K. C. and Li, J. (2008), "Audit committee and firm value: evidence on outside top executives as expert-independent directors", Corporate Governance: An International Review, Vol. 16 No. 1, pp. 16-31. 
Chau, G. and Gray, S.J. (2010), "Family ownership, board independence and voluntary disclosure: evidence from Hong Kong", Journal of International Accounting, Auditing and Taxation, Vol. 19 No. 2, pp. 93-109.

Chen, C.J. and Jaggi, B. (2000), "Association between independent non-executive directors, family control and financial disclosures in Hong Kong", Journal of Accounting and Public Policy, Vol. 19 No. 4-5, pp. 285-310.

Cheng, E.C. and Courtenay, S.M. (2006), "Board composition, regulatory regime and voluntary disclosure", The International Journal of Accounting, Vol. 41 No. 3, pp. 262-289.

Chizema, A. and Buck, T. (2006), "Neo-institutional theory and institutional change: towards empirical tests on the "Americanization" of German executive pay", International Business Review, Vol. 15 No. 5, pp. 488-504.

Ciocirlan, C. and Pettersson, C. (2012), "Does workforce diversity matter in the fight against climate change? An analysis of Fortune 500 companies", Corporate Social Responsibility and Environmental Management, Vol. 19, pp. 47-62.

Cong, Y. and Freedman, M. (2011), "Corporate governance and environmental performance and disclosures", Advances in Accounting, Vol. 27 No. 2, pp. 223-232.

Cormier, D., Magnan, M. and Van Velthoven, B. (2005), "Environmental disclosure quality in large German companies: economic incentives, public pressures or institutional conditions?", European Accounting Review, Vol. 14 No. 1, pp. 3-39.

Cramer, A. and Hirschland, M. (2006), "The socially responsible board: adding corporate social responsibility to your boardroom agenda", Corporate Board, Vol. 161, pp. 20-24.

Damayanthi, S. and Gooneratne, T. (2017), "Institutional logics perspective in management control research: a review of extant literature and directions for future research", Journal of Accounting and Organizational Change, Vol. 13 No. 4, pp. 520-547.

David, P., Bloom, M. and Hillman, A.J. (2007), "Investor activism, managerial responsiveness, and corporate social performance", Strategic Management Journal, Vol. 28 No. 1, pp. 91-100.

Dawkins, C. and Ngunjiri, F.W. (2008), "Corporate social responsibility reporting in South Africa: a descriptive and comparative analysis", The Journal of Business Communication, Vol. 45 No. 3, pp. 286-307.

De Villiers, C., Naiker, V. and Van Staden, C.J. (2011), "The effect of board characteristics on firm environmental performance”, Journal of Management, Vol. 37 No. 6, pp. 1636-1663.

Deegan, C. (2014), Financial Accounting Theory, McGraw-Hill Education, Australia.

DiMaggio P.J. and Powell W.W. (1983), "The iron cage revisited: institutional isomorphism and collective rationality in organizational fields", American Sociological Review, Vol. 48, pp. 147-160.

Dixon-Fowler, H.R., Ellstrand, A.E. and Johnson, J.L. (2017), "The role of board environmental committees in corporate environmental performance", Journal of Business Ethics, Vol. 140 No. 3, pp. 423-438.

Easterbrook, F.H. (1984), "Two agency-cost explanations of dividends", American Economic Review, Vol. 74 No. 4, pp. 650-659. 
Elgammal, W., El-Kassar, A.N. and Messarra, L.C. (2018), "Corporate ethics, governance and social responsibility in MENA countries”, Management Decision, Vol. 56 No.1, pp. 273-291.

Elmagrhi, M.H., Ntim, C.G. and Wang, Y. (2016), "Antecedents of voluntary corporate governance disclosure: a post-2007/08 financial crisis evidence from the influential UK Combined Code", Corporate Governance: The International Journal of Business in Society, Vol. 16 No. 3, pp. 507-538.

Elmagrhi, M.H., Ntim, C.G., Elamer, A.A. and Zhang, Q. (2018a), “A study of environmental policies and regulations, governance structures, and environmental performance: the role of female directors", Business Strategy and the Environment, Vol. 28 No. 1, pp. 206-220.

Elmagrhi, M.H., Ntim, C.G., Wang, Y., Abdou, H.A. and Zalata, A.M. (2018b), "Corporate governance disclosure index-executive pay nexus: the moderating effect of governance mechanisms", European Management Review, available at: https://doi.org/10.1111/emre.12329

Eljayash, K.M., James, K. and Kong, E. (2012), "The quantity and quality of environmental disclosure in annual report of national oil and gas companies in Middle East and North Africa", International Journal of Economics and Finance, Vol. 4 No. 10, pp. 201-217.

Elshandidy, T., Fraser, I. and Hussainey, K. (2015), "What drives mandatory and voluntary risk reporting variations across Germany, UK and US?", British Accounting Review, Vol. 47 No. 4, pp. 376-394.

Environmental Protection Agency (EPA). (2018), "EPA efforts in the Middle East", available at: https://www.epa.gov/international-cooperation/epa-efforts-middle-east (accessed 2 March 2019).

Erhardt, N.L., Werbel, J.D. and Shrader, C.B. (2003), "Board of director diversity and firm financial performance", Corporate Governance: An international Review, Vol. 11 No. 2, pp. 102-111.

Fama, E.F. and Jensen, M.C. (1983), "Separation of ownership and control", Journal of Law and Economics, Vol. 26 No. 2, pp. 301-325.

Felo, A.J., Krishnamurthy, S. and Solieri, S.A. (2003), "Audit committee characteristics and the perceived quality of financial reporting: an empirical analysis", Available at SSRN 401240.

Filatotchev, I. and Nakajima, C. (2014), "Corporate governance, responsible managerial behavior, and corporate social responsibility: organizational efficiency versus organizational legitimacy?", Academy of Management Perspectives, Vol. 28 No. 3, pp. 289-306.

Francoeur, C., Labelle, R., Balti, S. and Bouzaidi, S.E. (2019), "To what extent do gender diverse boards enhance corporate social performance?", Journal of business Ethics, Vol. 155 No. 2, pp. 343-357.

Freeman, R.E. and Reed, D.L. (1983), "Stockholders and stakeholders: a new perspective on corporate governance”, California Management Review, Vol. 25 No. 3, pp. 88-106.

Gerged, A.M., Cowton, C. J. and Beddewela, E.S. (2018), “Towards sustainable development in the Arab Middle East and North Africa region: a longitudinal analysis of environmental disclosure in corporate annual reports", Business Strategy and the Environment, Vol. 27 No. 4, pp. 572-587. 
Gibson, K. and O'Donovan, G. (2007), "Corporate governance and environmental reporting: an Australian study", Corporate Governance: An International Review, Vol. 15 No.5, pp. 944956.

Glass, C., Cook, A. and Ingersoll, A.R. (2016), "Do women leaders promote sustainability? Analysing the effect of corporate governance composition on environmental performance", Business Strategy and the Environment, Vol. 25, pp. 495-511.

Gompers, P., Ishii, J. and Metrick, A. (2003), "Corporate governance and equity prices", Quarterly Journal of Economics, Vol. 118 No. 1, pp. 107-156.

Graves, S.B. and Waddock, S.A. (1994), "Institutional owners and corporate social performance", Academy of Management Journal, Vol. 37 No. 4, pp. 1034-1046.

Greenwood, R. and Hinings, C.R. (1996), "Understanding radical organizational change: bringing together the old and the new institutionalism", Academy of Management Review, Vol. 21 No. 4, pp. 1022-1054.

Habbash, M. (2016), "Corporate governance and corporate social responsibility disclosure: evidence from Saudi Arabia", Social Responsibility Journal, Vol. 12 No. 4, pp. 740-754.

Haniffa, R.M. and Cooke, T.E. (2002), "Culture, corporate governance and disclosure in Malaysian corporations", Abacus, Vol. 38 No. 3, pp. 317-349.

Haniffa, R.M. and Cooke, T.E. (2005), “The impact of culture and governance on corporate social reporting", Journal of Accounting and Public Policy, Vol. 24 No. 5, pp. 391-430.

Haque, F. and Ntim, C. (2018), "Environmental policy, sustainable development, governance mechanisms and environmental performance", Business Strategy and the Environment, Vol. 27 No. 3, pp. 415-435.

Harrison, J.R. (1987), "The strategic use of corporate board committees", California Management Review, Vol. 30 No. 1, pp. 109-125.

Hasseldine, J., Salama, A.I. and Toms, J.S. (2005), "Quantity versus quality: the impact of environmental disclosures on the reputations of UK Plcs", British Accounting Review, Vol. 37 No. 2, pp. 231-248.

Hong, B., Li, Z. and Minor, D. (2016), "Corporate governance and executive compensation for corporate social responsibility”, Journal of Business Ethics, Vol. 136 No. 1, pp. 199-213.

Ibrahim, N.A. and Angelidis, J.P. (1995), "The corporate social responsiveness orientation of board members: are there differences between inside and outside directors?", Journal of Business Ethics, Vol. 14 No. 5, pp. 405-410.

Jensen, M.C. (1993), "The modern industrial revolution, exit, and the failure of internal control systems", Journal of Finance, Vol. 48 No. 3, pp. 831-880.

Jensen, M.C. and Meckling, W.H. (1976), “Theory of the firm: managerial behavior, agency costs and ownership structure", Journal of Financial Economics, Vol. 3, pp. 305-360.

Johnson, R.A. and Greening, D.W. (1999), "The effects of corporate governance and institutional ownership types on corporate social performance", Academy of Management Journal, Vol. 42 No. 5, pp. 564-576. 
Johnson, R.A., Hoskisson, R.E. and Hitt, M.A. (1993), "Board of director involvement in restructuring: the effects of board versus managerial controls and characteristics", Strategic Management Journal, Vol. 14 No. S1, pp. 33-50.

Jizi, M.I., Salama, A., Dixon, R. and Stratling, R. (2014), "Corporate governance and corporate social responsibility disclosure: evidence from the US banking sector", Journal of Business Ethics, Vol. 125 No. 4, pp. 601-615.

Jizi, M. (2017), "The influence of board composition on sustainable development disclosure", Business Strategy and the Environment, Vol. 26 No. 5, pp. 640-655.

Juhmani, O. (2014), "Determinants of corporate social and environmental disclosure on websites: the case of Bahrain", Universal Journal of Accounting and Finance, Vol. 2 No.4, pp. 77-87.

Judge, W., Li, S. and Pinsker, R. (2010), "National adoption of international accounting standards: an institutional perspective", Corporate Governance: An International Review, Vol. 18 No. 3, pp. 161-174.

Judge, W., Naoumova, I. and Koutzevol, N. (2003), "Corporate governance and firm performance in Russia: an empirical study", Journal of World Business, Vol. 38 No. 4, pp. 385 396.

Karim, K.E., Lacina, M.J. and Rutledge, R.W. (2006), "The association between firm characteristics and the level of environmental disclosure in financial statement footnotes", Environmental Accounting, pp. 77-109.

Kathy Rao, K., Tilt, C.A. and Lester, L.H. (2012), "Corporate governance and environmental reporting: an Australian study", Corporate Governance: The International Journal of Business in Society, Vol. 12 No. 2, pp. 143-163.

Khan, A., Muttakin, M.B. and Siddiqui, J. (2013), "Corporate governance and corporate social responsibility disclosures: evidence from an emerging economy", Journal of Business Ethics, Vol. 114 No. 2, pp. 207-223.

Kiesewetter, D. and Manthey, J. (2017), “Tax avoidance, value creation and CSR - a European perspective", Corporate Governance: The International Journal of Business in Society, Vol. 17 No. 7, pp. 803-821.

Kim, K.H., Al-Shammari, H.A., Kim, B. and Lee, S.H. (2009), "CEO duality leadership and corporate diversification behaviour", Journal of Business Research, Vol. 62 No. 11, pp. 11731180 .

Kolk, A. (2008), "Sustainability, accountability and corporate governance: exploring multinationals' reporting practices", Business Strategy and the Environment, Vol. 17 No. 1, pp. $1-15$.

Kyaw, K., Olugbode, M. and Petracci, B. (2017), "Can board gender diversity promote corporate social performance?", Corporate Governance: The International Journal of Business in Society, Vol. 17 No. 5, pp. 789-802.

Li, J., Pike, R. and Haniffa, R. (2008), "Intellectual capital disclosure and corporate governance structure in UK firms", Accounting and Business Research, Vol. 38 No. 2, pp. 137-159. 
Mallin, C., Michelon, G. and Raggi, D. (2013), "Monitoring intensity and stakeholders' orientation: how does governance affect social and environmental disclosure?", Journal of Business Ethics, Vol. 114 No. 1, pp. 29-43.

Mangena, M. and Pike, R. (2005), "The effect of audit committee shareholding, financial expertise and size on interim financial disclosures", Accounting and Business Research, Vol. 35 No. 4, pp. 327-349.

McGuinness, P.B., Vieito, J.P. and Wang, M. (2017), "The role of board gender and foreign ownership in the CSR performance of Chinese listed firms", Journal of Corporate Finance, Vol. 42, pp. 75-99.

Neubaum, D.O. and Zahra, S.A. (2006), "Institutional ownership and corporate social performance: the moderating effects of investment horizon, activism, and coordination", Journal of Management, Vol. 32 No. 1, pp. 108-131.

Ntim, C.G., Lindop, S., Thomas, D.A., Abdou, H. and Opong, K.K. (2017), "Executive pay and performance: the moderating effect of CEO power and governance structure", The International Journal of Human Resource Management, pp. 1-43.

Ntim, C.G. and Soobaroyen, T. (2013), "Black economic empowerment disclosures by South African listed corporations: the influence of ownership and board characteristics", Journal of Business Ethics, Vol. 116 No. 1, pp. 121-138.

Oliver, C. (1991), "Strategic responses to institutional processes", Academy of Management Review, Vol. 16 No. 1, pp. 145-179.

Parker, L.D. (2005), "Social and environmental accountability research: a view from the commentary box", Accounting, Auditing and Accountability Journal, Vol. 18 No. 6, pp. 842860 .

Persons, O.S. (2009), "Audit committee characteristics and earlier voluntary ethics disclosure among fraud and no-fraud firms", International Journal of Disclosure and Governance, Vol. 6 No. 4, pp. 284-297.

Pfeffer, J. and Salancik, G. (1978), The External Control of Organizations: A Resource Dependence Perspective, Harper \& Row, New York.

Prado-Lorenzo, J.M. and Garcia-Sanchez, I.M. (2010), "The role of the board of directors in disseminating relevant information on greenhouse gases", Journal of Business Ethics, Vol. 97 No. 3, pp. 391-424.

Raghunandan, K. and Rama, D.V. (2003), "Audit committee composition and shareholder actions: evidence from voting on auditor ratification", Auditing: A Journal of Practice and Theory, Vol. 22 No. 2, pp. 253-263.

Rahaman, A.S. (2000), "Senior management perceptions of social and environmental reporting in Ghana", Social and Environmental Accountability Journal, Vol. 20 No. 1, pp. 7-10.

Reverte, C. (2009), "Determinants of corporate social responsibility disclosure ratings by Spanish listed firms", Journal of Business Ethics, Vol. 88 No. 2, pp. 351-366.

Rizk, R., Dixon, R. and Woodhead, A. (2008), "Corporate social and environmental reporting: a survey of disclosure practices in Egypt", Social Responsibility Journal, Vol. 4 No. 3, pp. 306323. 
Ruigrok, W., Peck, S.I. and Keller, H. (2006), "Board characteristics and involvement in strategic decision making: evidence from Swiss companies", Journal of Management Studies, Vol. 43 No. 5, pp. 1201-1226.

Ruigrok, W., Peck, S.I. and Tacheva, S. (2007), "Nationality and gender diversity on Swiss corporate boards", Corporate Governance: An International Review, Vol. 15 No. 4, pp. 546557.

Salama, A., Dixon, R. and Habbash, M. (2012), "An examination of environmental disclosures in UK corporate annual reports", Journal of Accounting, Business and Management, Vol. 19 No. 1, pp. 19-42.

Salama, A., Anderson, K. and Toms, J.S. (2011), "Does community and environmental responsibility affect firm risk? Evidence from UK panel data 1994-2006", Business Ethics: A European Review, Vol. 20 No. 2, pp. 192-204.

Samaha, K., Khlif, H. and Hussainey, K. (2015), "The impact of board and audit committee characteristics on voluntary disclosure: a meta-analysis", Journal of International Accounting, Auditing and Taxation, Vol. 24, pp. 13-28.

Scott W.R. (2001), Institutions and Organizations, 2nd ed., Sage Publications Inc., Thousand Oaks, California.

Song, J. and Windram, B. (2004), "Benchmarking audit committee effectiveness in financial reporting”, International Journal of Auditing, Vol. 8 No. 3, pp. 195-205.

Suchman, M.C. (1995), "Managing legitimacy: strategic and institutional approaches", Academy of Management Review, Vol. 20 No. 3, pp. 571-610.

Shahab, Y., Ntim, C.G., Chengang, Y., Ullah, F. and Fosu, S. (2018), "Environmental policy, environmental performance, and financial distress in China: do top management team characteristics matter?", Business Strategy and the Environment, Vol. 27 No. 8, pp. 1635-1652.

Shahab, Y. and Ye, C. (2018), "Corporate social responsibility disclosure and corporate governance: empirical insights on neo-institutional framework from China", International Journal of Disclosure and Governance, Vol. 15 No. 2, pp. 87-103.

Shahbaz, M., Nasreen, S., Abbas, F. and Anis, O. (2015), "Does foreign direct investment impede environmental quality in high-, middle-, and low-income countries?", Energy Economics, Vol. 51, pp. 275-287.

The Official Portal of the UAE Government. (2018), "Dubai clean energy strategy”, available at: $\quad$ https://www.government.ae/en/about-the-uae/strategies-initiatives-and-awards/localgovernments-strategies-and-plans/dubai-clean-energy-strategy (accessed 3 March 2019).

Toms, J.S. (2002), "Firm resources, quality signals and the determinants of corporate environmental reputation: some UK evidence”, British Accounting Review, Vol. 34 No. 3, pp. 257-282.

Torchia, M., Calabrò, A. and Huse, M. (2011), "Women directors on corporate boards: from tokenism to critical mass", Journal of Business Ethics, Vol. 102 No. 2, pp. 299-317.

Walls, J.L., Berrone, P. and Phan, P.H. (2012), "Corporate governance and environmental performance: is there really a link?”, Strategic Management Journal, Vol. 33 No. 8, pp. 885913. 
Wasiuzzaman, S. and Mohammad, W.M. (2020), "Board gender diversity and transparency of environmental, social and governance disclosure: evidence from Malaysia", Managerial and Decision Economics, Vol. 41 No. 1, pp. 145-156.

Westphal, J.D. (1999), "Collaboration in the boardroom: behavioral and performance consequences of CEO-board social ties", Academy of Management Journal, Vol. 42 No. 1, pp. 7-24.

World Bank. (2014), "CO2 emissions (metric tons per capita), available at: https://data.worldbank.org/indicator/EN.ATM.CO2E.PC (accessed 5 March 2019).

World Health Organisation (WHO). (2016), "Ambient air pollution: a global assessment of exposure and burden of disease", The World Health Organisation, available at: http://apps.who.int/iris/bitstream/handle/10665/250141/9789241511353eng.pdf;jsessionid=7 765E54EC38EF81D733298B9DC8CC288? sequence=1 (accessed 2 March 2019).

Williams, R.J. (2003), "Women on corporate boards of directors and their influence on corporate philanthropy", Journal of Business Ethics, Vol. 42, pp. 1-10.

Yekini, K.C., Adelopo, I., Andrikopoulos, P. and Yekini, S. (2015), "Impact of board independence on the quality of community disclosures in annual reports", Accounting Forum, Vol. 39 No. 4, pp. 249-267.

Yermack, D. (1996), "Higher market valuation of companies with a small board of directors", Journal of Financial Economics, Vol. 40 No. 2, pp. 185-211.

Zahra, S.A. and Stanton, W.W. (1988), "The implications of board of directors composition for corporate strategy and performance", International Journal of Management, Vol. 5 No. 2, pp. 229-236.

Zhang, J.Q., Zhu, H. and Ding, H.B. (2013), "Board composition and corporate social responsibility: an empirical investigation in the post Sarbanes-Oxley era", Journal of Business Ethics, Vol. 114, pp. 381-392.

Zhang, L. (2012), "Board demographic diversity, independence, and corporate social performance", Corporate Governance: The International Journal of Business in Society, Vol. 12 No. 5, pp. 686-700.

Zattoni, A. and Cuomo, F. (2008), "Why adopt codes of good governance? A comparison of institutional and efficiency perspectives", Corporate Governance: An International Review, Vol. 16 No. 1, pp. 1-15.

Zou, H., Xie, X., Qi, G. and Yang, M. (2019), “The heterogeneous relationship between board social ties and corporate environmental responsibility in an emerging economy", Business Strategy and the Environment, Vol. 28 No. 1, pp. 40-52.

Zou, H., Zeng, R.C., Zeng, S.X. and Shi, J.J. (2015), "How do environmental violation events harm corporate reputation?", Business Strategy and the Environment, Vol. 24 No. 8, pp. 836854. 
Table 1. Sample distribution across countries, time and industries

\begin{tabular}{|c|c|c|c|c|c|c|}
\hline \multicolumn{3}{|c|}{ Panel A } & \multicolumn{2}{|c|}{ Panel B } & \multicolumn{2}{|l|}{ Panel C } \\
\hline \multicolumn{3}{|c|}{ Distribution across countries } & \multicolumn{2}{|c|}{ Distribution across years } & \multicolumn{2}{|c|}{ Distribution across industries } \\
\hline Country & $\begin{array}{l}\text { Number } \\
\text { of firms }\end{array}$ & $\begin{array}{c}\text { Number of } \\
\text { observations }\end{array}$ & Years & $\begin{array}{l}\text { Number } \\
\text { of firms }\end{array}$ & Industry & Sample $(\%)$ \\
\hline Botswana & 1 & 5 & 2010 & 34 & Communication & 10.7 \\
\hline Israel & 8 & 45 & 2011 & 73 & Consumer discretionary & 16.2 \\
\hline Kenya & 1 & 4 & 2012 & 77 & Consumer staples & 21.8 \\
\hline Mauritius & 3 & 9 & 2013 & 81 & Energy & 2.7 \\
\hline Nigeria & 5 & 14 & 2014 & 87 & Health care & 6.5 \\
\hline Oman & 2 & 4 & 2015 & 90 & Industrials & 11.8 \\
\hline Qatar & 2 & 4 & 2016 & 87 & Materials & 27.1 \\
\hline Saudi Arabia & 2 & 4 & 2017 & 88 & Technology & 3.2 \\
\hline South Africa & 90 & 475 & & & Total & $100 \%$ \\
\hline UAE & 6 & 16 & & & & \\
\hline Zambia & 1 & 7 & & & & \\
\hline Total & 121 & 587 & & & & \\
\hline
\end{tabular}


Table 2. Research variables and definitions

\begin{tabular}{|c|c|c|}
\hline Variable & Abbreviation & Definition \\
\hline \multicolumn{3}{|l|}{ Dependent variables } \\
\hline Environmental disclosure & E-SCORE & $\begin{array}{l}\text { Bloomberg's environmental disclosure score that measures the amount of environmental data which a firm } \\
\text { reports publicly. The score ranges from } 0.1 \text { for firms that disclose a minimum environmental data to } 100 \text { for } \\
\text { those that disclose every data point (e.g., air quality, climate change, water \& energy management and } \\
\text { materials \& waste) collected by Bloomberg. }\end{array}$ \\
\hline $\begin{array}{l}\text { The probability of having higher } \\
\text { environmental disclosure }\end{array}$ & E-CODE & $\begin{array}{l}\text { A binary variable }(0 / 1) \text { that equals } 1 \text { if the firm has high environmental disclosure (with an environmental } \\
\text { score which is higher than the mean E-SCORE) and } 0 \text { otherwise (low environmental disclosure). }\end{array}$ \\
\hline \multicolumn{3}{|r|}{ ( } \\
\hline Governance quality index & G-SCORE & $\begin{array}{l}\text { Bloomberg's governance disclosure score that measures the amount of governance data which a firm reports } \\
\text { publicly. The score ranges from } 0.1 \text { for firms that disclose a minimum governance data to } 100 \text { for those that } \\
\text { disclose every data point (e.g., board independence, structure and tenure, compensation, diversity and } \\
\text { shareholders' rights) collected by Bloomberg. }\end{array}$ \\
\hline Female board presentation & FEMDIR & Fraction of female directors to board size. \\
\hline Board size & BSIZE & Total number of directors on the board. \\
\hline Board independence & BINDEP & Fraction of independent directors to board size. \\
\hline CEO/chairperson duality & DUAL & Dummy variable that equals 1 if the CEO is also the chairperson, 0 otherwise. \\
\hline Audit committee & AUDIT & Total number of directors who serve on the audit committee. \\
\hline \multicolumn{3}{|l|}{ Control variables } \\
\hline Insider ownership & INSIDER & Proportion of outstanding shares held by insiders. \\
\hline Institutional ownership & INST & Proportion of outstanding shares owned by institutional investors. \\
\hline Profitability & ROA & Ratio of net earnings to total assets. \\
\hline Debt ratio & DEBT & Ratio of total debt to total assets. \\
\hline Firm growth & GROW & Market-to-book value ratio. \\
\hline Firm size & FSIZE & Natural log of annualised sales revenue. \\
\hline Firm age & AGE & Natural log of total number of years since incorporation. \\
\hline Country effect & COUNTRY & Country dummies representing 11 different countries in Middle East and Africa. \\
\hline Industry effect & INDUSTRY & Industry dummies representing eight different industry classifications based on the BICS. \\
\hline Time effect & YEAR & Yearly dummies between 2010 and 2017, which take a value of 1 for the particular year and 0 otherwise. \\
\hline
\end{tabular}


Table 3. Descriptive statistics by country

Panel A: Environmental disclosure, governance quality score and board characteristics

\begin{tabular}{|c|c|c|c|c|c|c|c|c|c|c|c|c|c|c|c|c|c|c|c|c|c|c|}
\hline \multirow{2}{*}{ Country } & \multirow{2}{*}{$\begin{array}{c}\text { Firm-year } \\
\text { observations }\end{array}$} & \multicolumn{3}{|c|}{ E-SCORE } & \multicolumn{3}{|c|}{ G-SCORE } & \multicolumn{3}{|c|}{ FEMDIR } & \multicolumn{3}{|c|}{ BSIZE } & \multicolumn{3}{|c|}{ BINDEP } & \multicolumn{3}{|c|}{ DUAL } & \multicolumn{3}{|c|}{ AUDIT } \\
\hline & & Mean & Median & S.D. & Mean & Median & S.D. & Mean & Median & S.D. & Mean & Median & S.D. & Mean & Median & S.D. & Mean & Median & S.D. & Mean & Median & S.D. \\
\hline Botswana & 5 & 21.40 & 19.38 & 5.82 & 58.21 & 57.14 & 2.40 & 0.000 & 0.000 & 0.00 & 13.20 & 13.00 & 1.64 & 0.430 & 0.417 & 0.09 & 0.000 & 0.000 & 0.00 & 3.000 & 3.000 & 0.00 \\
\hline Israel & 45 & 20.12 & 4.88 & 19.67 & 43.57 & 37.5 & 10.47 & 0.149 & 0.125 & 0.08 & 10.11 & 9.00 & 2.19 & 0.539 & 0.428 & 0.30 & 0.000 & 0.000 & 0.00 & 4.044 & 4.000 & 0.98 \\
\hline Kenya & 4 & 26.55 & 26.74 & 2.99 & 55.80 & 57.14 & 2.68 & 0.305 & 0.333 & 0.06 & 9.00 & 9.00 & 0.00 & 0.861 & 0.888 & 0.05 & 0.000 & 0.000 & 0.00 & 4.000 & 4.000 & 0.00 \\
\hline Mauritius & 9 & 13.09 & 10.85 & 4.80 & 56.75 & 57.15 & 4.53 & 0.030 & 0.000 & 0.05 & 11.11 & 11.00 & 0.60 & 0.229 & 0.250 & 0.04 & 0.000 & 0.000 & 0.00 & 3.777 & 4.000 & 0.66 \\
\hline Nigeria & 14 & 12.02 & 8.53 & 12.02 & 47.45 & 48.21 & 3.55 & 0.121 & 0.117 & 0.09 & 12.86 & 13.50 & 2.74 & 0.219 & 0.188 & 0.12 & 0.000 & 0.000 & 0.00 & 6.143 & 6.000 & 1.17 \\
\hline Oman & 4 & 18.50 & 18.71 & 4.16 & 53.57 & 55.36 & 3.57 & 0.000 & 0.000 & 0.000 & 8.00 & 8.00 & 0.82 & 1.000 & 1.000 & 0.00 & 0.000 & 0.000 & 0.00 & 4.000 & 4.000 & 0.82 \\
\hline Qatar & 4 & 30.23 & 24.23 & 14.77 & 39.73 & 41.96 & 6.74 & 0.091 & 0.111 & 0.06 & 8.50 & 9.00 & 1.00 & 0.250 & 0.333 & 0.17 & 0.000 & 0.000 & 0.00 & 3.250 & 3.000 & 0.50 \\
\hline Saudi Arabia & 4 & 10.66 & 4.65 & 12.01 & 48.21 & 48.21 & 4.37 & 0.028 & 0.000 & 0.05 & 8.75 & 9.00 & 0.50 & 0.312 & 0.333 & 0.04 & 0.000 & 0.000 & 0.00 & 5.250 & 5.000 & 0.50 \\
\hline South Africa & 475 & 28.14 & 27.91 & 13.83 & 58.72 & 57.14 & 6.28 & 0.210 & 0.200 & 0.11 & 11.60 & 11.00 & 2.45 & 0.593 & 0.600 & 0.14 & 0.008 & 0.000 & 0.09 & 3.716 & 4.000 & 0.85 \\
\hline UAE & 16 & 21.43 & 21.32 & 11.80 & 52.57 & 52.67 & 5.97 & 0.039 & 0.000 & 0.05 & 8.00 & 8.00 & 1.86 & 0.681 & 0.732 & 0.15 & 0.125 & 0.000 & 0.34 & 3.625 & 3.000 & 0.89 \\
\hline Zambia & 7 & 9.19 & 10.85 & 2.21 & 48.98 & 48.21 & 4.48 & 0.194 & 0.200 & 0.05 & 11.57 & 12.00 & 1.72 & 0.313 & 0.333 & 0.08 & 0.000 & 0.000 & 0.00 & 2.857 & 3.000 & 0.38 \\
\hline Total & 587 & 26.22 & 27.08 & 14.54 & 56.72 & 57.14 & 8.04 & 0.191 & 0.182 & 0.11 & 11.34 & 11.00 & 2.52 & 0.573 & 0.600 & 0.18 & 0.010 & 0.000 & 0.10 & 3.792 & 4.000 & 0.94 \\
\hline ANOVA $(F)$ & & & $5.92 * * *$ & & & $30.40 * * *$ & & & $13.47 * * *$ & & & $8.02 * * *$ & & & $23.02 * * *$ & & & $2.24 * *$ & & & $14.16^{* * *}$ & \\
\hline Kruskal-Wallis & $\left(\chi^{2}\right)$ & & $55.37 * * *$ & & & $131.40^{* * *}$ & & & $111.37 * * *$ & & & $73.66^{* * * *}$ & & & $125.89^{* * *}$ & & & $21.94 * *$ & & & $64.79^{* * *}$ & \\
\hline \multicolumn{23}{|c|}{ Panel B: Ownership and financial characteristics } \\
\hline \multirow{2}{*}{ Country } & \multirow{2}{*}{$\begin{array}{c}\text { Firm-year } \\
\text { observations }\end{array}$} & \multicolumn{3}{|c|}{ INSIDER } & \multicolumn{3}{|c|}{ INST } & \multicolumn{3}{|c|}{ ROA } & \multicolumn{3}{|c|}{ DEBT } & \multicolumn{3}{|c|}{ GROW } & \multicolumn{3}{|c|}{ FSIZE } & \multicolumn{3}{|c|}{ AGE } \\
\hline & & Mean & Median & S.D. & Mean & Median & S.D. & Mean & Median & S.D. & Mean & Median & S.D. & Mean & Median & S.D. & Mean & Median & S.D. & Mean & Median & S.D. \\
\hline Botswana & 5 & 0.143 & 0.097 & 0.14 & 0.365 & 0.435 & 0.21 & 0.057 & 0.054 & 0.03 & 0.100 & 0.109 & 0.04 & 1.347 & 1.217 & 0.23 & 4.765 & 4.646 & 0.26 & 3.433 & 3.434 & 0.05 \\
\hline Israel & 45 & 0.002 & 0.000 & 0.01 & 0.315 & 0.201 & 0.26 & 0.043 & 0.036 & 0.07 & 0.247 & 0.203 & 0.17 & 1.805 & 1.662 & 0.62 & 8.035 & 7.580 & 1.15 & 3.548 & 3.433 & 0.79 \\
\hline Kenya & 4 & 0.000 & 0.000 & 0.00 & 0.802 & 0.806 & 0.01 & 0.190 & 0.191 & 0.05 & 0.034 & 0.021 & 0.04 & 3.847 & 4.221 & 1.09 & 7.450 & 7.470 & 0.12 & 2.860 & 2.862 & 0.07 \\
\hline Mauritius & 9 & 0.020 & 0.017 & 0.02 & 0.284 & 0.318 & 0.28 & 0.016 & 0.017 & 0.02 & 0.169 & 0.180 & 0.13 & 1.194 & 1.321 & 0.41 & 4.854 & 4.847 & 0.11 & 4.048 & 3.497 & 0.87 \\
\hline Nigeria & 14 & 0.004 & 0.002 & 0.01 & 0.135 & 0.044 & 0.20 & 0.121 & 0.132 & 0.08 & 0.119 & 0.104 & 0.08 & 3.997 & 3.786 & 1.99 & 7.312 & 7.338 & 0.37 & 3.698 & 3.980 & 0.51 \\
\hline Oman & 4 & 0.000 & 0.000 & 0.00 & 0.543 & 0.708 & 0.34 & 0.104 & 0.152 & 0.10 & 0.143 & 0.032 & 0.23 & 1.599 & 1.672 & 0.19 & 6.932 & 7.087 & 0.34 & 2.658 & 2.602 & 0.20 \\
\hline Qatar & 4 & 0.000 & 0.000 & 0.00 & 0.104 & 0.100 & 0.11 & 0.024 & 0.030 & 0.04 & 0.200 & 0.062 & 0.32 & 1.996 & 1.950 & 0.29 & 6.468 & 6.409 & 0.20 & 2.076 & 2.012 & 0.30 \\
\hline Saudi Arabia & 4 & 0.000 & 0.000 & 0.00 & 0.640 & 0.614 & 0.09 & 0.019 & 0.011 & 0.03 & 0.417 & 0.499 & 0.19 & 1.583 & 1.552 & 0.11 & 8.593 & 7.972 & 1.34 & 3.095 & 2.917 & 0.41 \\
\hline South Africa & 475 & 0.010 & 0.001 & 0.03 & 0.606 & 0.645 & 0.30 & 0.073 & 0.064 & 0.13 & 0.124 & 0.096 & 0.12 & 2.037 & 1.717 & 1.12 & 7.464 & 7.395 & 1.09 & 3.696 & 3.828 & 0.79 \\
\hline UAE & 16 & 0.013 & 0.000 & 0.02 & 0.535 & 0.59 & 0.28 & 0.068 & 0.050 & 0.04 & 0.191 & 0.189 & 0.11 & 1.600 & 1.691 & 0.38 & 7.317 & 7.940 & 1.35 & 2.328 & 2.250 & 0.64 \\
\hline Zambia & 7 & 0.000 & 0.000 & 0.00 & 0.014 & 0.000 & 0.04 & 0.039 & 0.060 & 0.03 & 0.377 & 0.371 & 0.07 & 1.825 & 1.813 & 0.23 & 5.615 & 5.694 & 0.14 & 3.911 & 3.912 & 0.04 \\
\hline Total & 587 & 0.010 & 0.001 & 0.03 & 0.549 & 0.587 & 0.31 & 0.070 & 0.061 & 0.12 & 0.141 & 0.107 & 0.13 & 2.038 & 1.709 & 1.13 & 7.412 & 7.366 & 1.17 & 3.625 & 3.784 & 0.82 \\
\hline \multirow{2}{*}{\multicolumn{2}{|c|}{$\begin{array}{l}\text { ANOVA }(F) \\
\text { Kruskal-Wallis }\left(\chi^{2}\right)\end{array}$}} & \multirow{2}{*}{\multicolumn{3}{|c|}{$\begin{array}{l}11.17 * * * \\
89.11 * * *\end{array}$}} & & & & & $3.91 * * *$ & & & $9.39 * * *$ & & & $7.15^{* * * *}$ & & & $12.77 * * *$ & & & $8.21 * * *$ & \\
\hline & & & & & & $99.77 * * *$ & & & $50.14 * * *$ & & & $56.04 * * *$ & & & $38.16 * * *$ & & & $70.26 * * *$ & & & $56.95 * * *$ & \\
\hline
\end{tabular}

$* * *$ Significance at the $1 \%$ level $(\mathrm{p}<0.01)$

** Significance at the 5\% level $(\mathrm{p}<0.05)$ 
Table 4. Pearson's correlations and VIF values

\begin{tabular}{|c|c|c|c|c|c|c|c|c|c|c|c|c|c|c|}
\hline Variables & $(1)$ & $(2)$ & (3) & (4) & (5) & (6) & (7) & $(8)$ & (9) & $(10)$ & (11) & (12) & (13) & VIF \\
\hline (1) G-SCORE & 1.000 & & & & & & & & & & & & & 1.25 \\
\hline (2) FEMDIR & $0.190 * *$ & 1.000 & & & & & & & & & & & & 1.14 \\
\hline (3) BSIZE & $0.238 * *$ & 0.058 & 1.000 & & & & & & & & & & & 1.42 \\
\hline (4) BINDEP & $0.223 * *$ & $0.240^{* *}$ & -0.073 & 1.000 & & & & & & & & & & 1.34 \\
\hline (5) DUAL & -0.055 & 0.013 & -0.007 & 0.084 & 1.000 & & & & & & & & & 1.04 \\
\hline (6) AUDIT & 0.056 & 0.004 & $0.302 * *$ & $0.124^{*}$ & -0.032 & 1.000 & & & & & & & & 1.22 \\
\hline (7) INSIDER & 0.004 & $-0.208^{* *}$ & -0.064 & $-0.157 * *$ & -0.032 & $-0.157 * *$ & 1.000 & & & & & & & 1.14 \\
\hline (8) INST & $0.303 * *$ & $0.168 * *$ & $0.145^{* *}$ & $0.324 * *$ & 0.104 & 0.013 & $-0.162 * *$ & 1.000 & & & & & & 1.31 \\
\hline (9) ROA & -0.075 & 0.031 & -0.003 & 0.008 & -0.026 & -0.010 & 0.049 & -0.001 & 1.000 & & & & & 1.31 \\
\hline (10) DEBT & $-0.144 * *$ & -0.064 & 0.027 & $-0.138 * *$ & 0.096 & 0.100 & $-0.124^{*}$ & -0.056 & $-0.133^{*}$ & 1.000 & & & & 1.13 \\
\hline (11) GROW & -0.059 & 0.038 & -0.023 & -0.075 & -0.033 & 0.065 & -0.018 & 0.052 & $0.451 * *$ & 0.011 & 1.000 & & & 1.31 \\
\hline (12) FSIZE & 0.096 & 0.086 & $0.330 * *$ & $0.149 * *$ & 0.045 & $0.216^{* *}$ & $-0.128 *$ & $0.164 * *$ & 0.015 & $0.118 *$ & 0.033 & 1.000 & & 1.21 \\
\hline (13) AGE & $0.129 *$ & 0.086 & $0.231 * *$ & 0.016 & -0.030 & -0.066 & -0.088 & $0.224 * *$ & 0.001 & -0.101 & 0.033 & 0.061 & 1.000 & 1.15 \\
\hline
\end{tabular}

** Significance at the $1 \%$ level $(\mathrm{p}<0.01)$

* Significance at the $5 \%$ level $(\mathrm{p}<0.05)$ 
Table 5. Regression results

The table reports the coefficients and standard errors in the parentheses. All estimations (both WLS and OLS) are computed using White's corrected heteroscedasticity robust regressions.

\begin{tabular}{|c|c|c|c|c|c|}
\hline \multicolumn{6}{|c|}{ Dependent variable: $\mathrm{E}^{-\mathrm{SCORE}_{i, k, t}}$} \\
\hline \multirow[t]{2}{*}{ Estimation method: } & WLS & WLS & OLS & WLS & WLS \\
\hline & $\begin{array}{l}\text { Full sample } \\
\text { (1) }\end{array}$ & $\begin{array}{l}\text { Non-South Africa } \\
\text { (2) }\end{array}$ & $\begin{array}{l}\text { South Africa } \\
\text { (3) }\end{array}$ & $\begin{array}{l}\text { Middle East } \\
\text { (4) }\end{array}$ & $\begin{array}{l}\text { Africa } \\
(5)\end{array}$ \\
\hline \multicolumn{6}{|l|}{ Independent variables } \\
\hline \multicolumn{6}{|l|}{ Test variables } \\
\hline $\mathrm{G}-\mathrm{SCORE}_{i, k, t}$ & $\begin{array}{c}0.673 * * * \\
(0.1116)\end{array}$ & $\begin{array}{c}0.465 * * * \\
(0.1617)\end{array}$ & $\begin{array}{c}0.536 * * * \\
(0.0933)\end{array}$ & $\begin{array}{l}0.500^{* * *} \\
(0.2302)\end{array}$ & $\begin{array}{l}0.288 * * * \\
(0.10000)\end{array}$ \\
\hline FEMDIR $_{i, k, t}$ & $\begin{array}{c}0.251 * * * \\
(0.0866)\end{array}$ & $\begin{array}{c}0.486 * * * \\
(0.1699)\end{array}$ & $\begin{array}{l}0.125 * * \\
(0.0508)\end{array}$ & $\begin{array}{c}0.416^{*} \\
(0.2122)\end{array}$ & $\begin{array}{l}0.230 * * * \\
(0.0656)\end{array}$ \\
\hline BSIZE $_{i, k, t}$ & $\begin{array}{c}0.063 \\
(0.4203)\end{array}$ & $\begin{array}{c}0.902 \\
(0.6681)\end{array}$ & $\begin{array}{l}0.554 * * \\
(0.2588)\end{array}$ & $\begin{array}{c}0.369 \\
(0.9631)\end{array}$ & $\begin{array}{c}0.455 \\
(0.3160)\end{array}$ \\
\hline $\mathrm{BINDEP}_{i, k, t}$ & $\begin{array}{c}-0.136^{* * * *} \\
(0.0438)\end{array}$ & $\begin{array}{c}-0.305^{* * *} \\
(0.0809)\end{array}$ & $\begin{array}{c}-0.080^{* *} \\
(0.0403)\end{array}$ & $\begin{array}{c}-0.429 * * * \\
(0.1110)\end{array}$ & $\begin{array}{l}-0.079^{*} \\
(0.0430)\end{array}$ \\
\hline DUAL $_{i, k, t}$ & $\begin{array}{l}9.681 * * \\
(3.9047)\end{array}$ & $\begin{array}{l}11.351^{*} \\
(5.7788)\end{array}$ & $\begin{array}{c}8.253 \\
(6.5381)\end{array}$ & $\begin{array}{c}19.381 * * \\
(8.1885)\end{array}$ & $\begin{array}{c}6.989 \\
(9.7592)\end{array}$ \\
\hline $\operatorname{AUDIT}_{i, k, t}$ & $\begin{array}{c}1.410 \\
(0.9175)\end{array}$ & $\begin{array}{l}3.643 * * \\
(1.6859)\end{array}$ & $\begin{array}{c}0.048 \\
(0.6705)\end{array}$ & $\begin{array}{l}5.553 * * \\
(2.2087)\end{array}$ & $\begin{array}{c}1.120 * \\
(0.6657)\end{array}$ \\
\hline \multicolumn{6}{|l|}{ Control variables } \\
\hline $\operatorname{INSIDER}_{i, k, t}$ & $\begin{array}{c}-0.108 \\
(0.1842)\end{array}$ & $\begin{array}{c}-0.356 \\
(0.3581)\end{array}$ & $\begin{array}{c}-0.662 * * * \\
(0.1298)\end{array}$ & $\begin{array}{c}-0.776 \\
(0.4857)\end{array}$ & $\begin{array}{c}-0.588^{* * * *} \\
(0.1398)\end{array}$ \\
\hline $\mathrm{INST}_{i, k, t}$ & $\begin{array}{c}-0.097 * * * \\
(0.0306)\end{array}$ & $\begin{array}{c}-0.116^{* * *} \\
(0.0541)\end{array}$ & $\begin{array}{l}-0.034 \\
(0.0229)\end{array}$ & $\begin{array}{c}-0.208^{* * * *} \\
(0.0632)\end{array}$ & $\begin{array}{l}-0.033 \\
(0.0239)\end{array}$ \\
\hline $\mathrm{ROA}_{i, k, t}$ & $\begin{array}{c}-0.227 * * \\
(0.0942)\end{array}$ & $\begin{array}{c}-0.844 * * * * \\
(0.2818)\end{array}$ & $\begin{array}{c}-0.078 * * * \\
(0.0207)\end{array}$ & $\begin{array}{c}-0.782 * * \\
(0.3205)\end{array}$ & $\begin{array}{c}-0.111 * * * \\
(0.0353)\end{array}$ \\
\hline DEBT $_{i, k, t}$ & $\begin{array}{c}-0.195^{* * * *} \\
(0.0540)\end{array}$ & $\begin{array}{c}-0.223 * * * \\
(0.0678)\end{array}$ & $\begin{array}{c}-0.143^{* * *} \\
(0.0490)\end{array}$ & $\begin{array}{c}-0.263 * * \\
(0.1037)\end{array}$ & $\begin{array}{c}-0.178 * * \\
(0.0681)\end{array}$ \\
\hline $\mathrm{GROW}_{i, c, t}$ & $\begin{array}{c}1.250 \\
(1.0665)\end{array}$ & $\begin{array}{c}0.982 \\
(1.7841)\end{array}$ & $\begin{array}{c}0.458 \\
(0.4431)\end{array}$ & $\begin{array}{c}1.031 \\
(0.7312)\end{array}$ & $\begin{array}{c}1.409 \\
(1.1272)\end{array}$ \\
\hline FSIZE $_{i, k, t}$ & $\begin{array}{c}2.877 * * * * \\
(0.7244)\end{array}$ & $\begin{array}{c}5.433 * * * \\
(1.2894)\end{array}$ & $\begin{array}{l}1.573 * * * \\
(0.5575)\end{array}$ & $\begin{array}{l}7.368 * * * \\
(2.0304)\end{array}$ & $\begin{array}{l}5.811 * * * \\
(1.9969)\end{array}$ \\
\hline $\mathrm{AGE}_{i, k, t}$ & $\begin{array}{l}4.785 * * * \\
(1.3969)\end{array}$ & $\begin{array}{l}9.011 * * * \\
(2.9692)\end{array}$ & $\begin{array}{l}1.562 * * \\
(0.6687)\end{array}$ & $\begin{array}{c}8.961 * \\
(5.3023)\end{array}$ & $\begin{array}{l}1.889 * * \\
(0.9334)\end{array}$ \\
\hline COUNTRY & Yes & Yes & - & Yes & Yes \\
\hline INDUSTRY & Yes & Yes & Yes & Yes & Yes \\
\hline YEAR & Yes & Yes & Yes & Yes & Yes \\
\hline Constant & $\begin{array}{c}-60.228 * * * \\
(7.9919) \\
\end{array}$ & $\begin{array}{c}-63.871 * * * \\
(15.1238) \\
\end{array}$ & $\begin{array}{c}-34.188 * * * \\
(7.5107) \\
\end{array}$ & $\begin{array}{c}-42.463 * * \\
(20.9045) \\
\end{array}$ & $\begin{array}{c}-25.474 * * * * \\
(7.2800) \\
\end{array}$ \\
\hline No. of observations & 587 & 112 & 475 & 78 & 509 \\
\hline$F$-Statistic & $42.59 * * *$ & $27.70 * * *$ & $41.63^{* * *}$ & $8.68 * * *$ & $68.12 * * *$ \\
\hline$R^{2}(\%)$ & $71.48 \%$ & $79.21 \%$ & $51.71 \%$ & $74.96 \%$ & $75.07 \%$ \\
\hline
\end{tabular}


Table 6. Regression results using lagged independent variables

The table reports the coefficients and standard errors in the parentheses. All estimations (both WLS and OLS) are computed using White's corrected heteroscedasticity robust regressions. Independent variables are one-year lagged.

\begin{tabular}{|c|c|c|c|c|c|}
\hline \multicolumn{6}{|c|}{ Dependent variable: $\mathrm{E}_{-\mathrm{SCORE}} \mathrm{i}_{i, t, t}$} \\
\hline \multirow[t]{2}{*}{ Estimation method: } & WLS & WLS & OLS & WLS & WLS \\
\hline & $\begin{array}{l}\text { Full sample } \\
\text { (1) }\end{array}$ & $\begin{array}{l}\text { Non-South Africa } \\
\text { (2) }\end{array}$ & $\begin{array}{c}\text { South Africa } \\
\text { (3) }\end{array}$ & $\begin{array}{l}\text { Middle East } \\
\text { (4) }\end{array}$ & $\begin{array}{l}\text { Africa } \\
(5)\end{array}$ \\
\hline \multicolumn{6}{|l|}{ Independent variables } \\
\hline \multicolumn{6}{|l|}{ Test variables } \\
\hline \multirow{2}{*}{$\mathrm{G}-\mathrm{SCORE}_{i, k, t-1}$} & $0.478 * * *$ & $0.491 * *$ & $0.583 * * *$ & $0.305 * *$ & $0.201 * *$ \\
\hline & $(0.1099)$ & $(0.1917)$ & $(0.0960)$ & $(0.1488)$ & $(0.0939)$ \\
\hline \multirow{2}{*}{ FEMDIR $_{i, k, t-1}$} & $0.203^{* *}$ & $0.215^{* *}$ & $0.137 * *$ & $0.289^{*}$ & $0.110 * *$ \\
\hline & $(0.0838)$ & $(0.0931)$ & $(0.0615)$ & $(0.1537)$ & $(0.0553)$ \\
\hline \multirow{2}{*}{$\operatorname{BSIZE}_{i, k, t-1}$} & 0.244 & 0.810 & $0.465 * *$ & 0.499 & 0.376 \\
\hline & $(0.4249)$ & $(0.7941)$ & $(0.1875)$ & $(1.2438)$ & $(0.3581)$ \\
\hline \multirow{2}{*}{$\mathrm{BINDEP}_{i, k, t-1}$} & $-0.108 * *$ & $-0.156^{*}$ & $-0.082 *$ & $-0.365^{* * *}$ & $-0.089 * *$ \\
\hline & $(0.0441)$ & $(0.0830)$ & $(0.0435)$ & $(0.1250)$ & $(0.0415)$ \\
\hline \multirow{2}{*}{ DUAL $_{i, k, t-1}$} & $1.969 * *$ & $8.708^{*}$ & 8.122 & $7.157 * * *$ & 5.577 \\
\hline & $(0.9107)$ & (4.9197) & $(6.8335)$ & $(2.6312)$ & $(4.8495)$ \\
\hline \multirow{2}{*}{ AUDIT $_{i, k, t-1}$} & 2.058 & $2.823 * *$ & 0.043 & $6.257 * *$ & $2.196 * * *$ \\
\hline & $(4.5490)$ & $(1.2381)$ & $(0.7651)$ & $(2.7933)$ & $(0.7362)$ \\
\hline \multicolumn{6}{|l|}{ Control variables } \\
\hline \multirow{2}{*}{ INSIDER $_{i, k, t-1}$} & -0.028 & -0.096 & $-0.664 * * *$ & -0.645 & $-0.666 * * *$ \\
\hline & $(0.0340)$ & $(0.0849)$ & $(0.1592)$ & $(0.4313)$ & $(0.1584)$ \\
\hline \multirow{2}{*}{$\mathrm{INST}_{i, k, t-1}$} & $-0.3369 * *$ & $-0.800^{* * *}$ & -0.044 & $-0.143^{* *}$ & -0.053 \\
\hline & $(0.1674)$ & $(0.2627)$ & $(0.0288)$ & $(0.0612)$ & $(0.0445)$ \\
\hline \multirow{2}{*}{$\mathrm{ROA}_{i, k, t-1}$} & $-0.235^{* *}$ & $-0.653 * *$ & $-0.093 * * *$ & $-0.568 * *$ & $-0.090 * * *$ \\
\hline & $(0.0987)$ & $(0.3069)$ & $(0.0233)$ & $(0.2691)$ & $(0.0331)$ \\
\hline \multirow{2}{*}{$\operatorname{DEBT}_{i, k, t-1}$} & $-0.108 * * *$ & $-0.061^{* *}$ & $-0.199 * * *$ & $-0.234^{*}$ & $-0.151 * *$ \\
\hline & $(0.0413)$ & $(0.0264)$ & $(0.0523)$ & $(0.1353)$ & $(0.0672)$ \\
\hline \multirow{2}{*}{ GROW $_{i, k, t-1}$} & 0.707 & 1.298 & 0.775 & 1.248 & 1.018 \\
\hline & $(0.5001)$ & $(2.1328)$ & $(0.4765)$ & $(3.5031)$ & $(0.8566)$ \\
\hline \multirow{2}{*}{ FSIZE $_{i, k, t-1}$} & $3.692 * * *$ & $11.127 * * *$ & $1.671 * *$ & $8.936^{* *}$ & $3.259 * *$ \\
\hline & $(0.6493)$ & $(2.1455)$ & $(0.6637)$ & $(4.2907)$ & $(1.5445)$ \\
\hline \multirow{2}{*}{$\mathrm{AGE}_{i, k, t-1}$} & $4.922 * * *$ & $14.097 * * *$ & $1.699 * *$ & $8.113^{*}$ & $2.573^{* *}$ \\
\hline & $(0.9033)$ & $(4.1922)$ & $(0.7281)$ & $(4.7445)$ & $(0.8381)$ \\
\hline COUNTRY & Yes & Yes & - & Yes & Yes \\
\hline INDUSTRY & Yes & Yes & Yes & Yes & Yes \\
\hline YEAR & Yes & Yes & Yes & Yes & Yes \\
\hline \multirow[t]{2}{*}{ Constant } & $-65.300 * * *$ & $-78.991 * * *$ & $-31.475^{* * *}$ & $-32.236 * * *$ & $-23.104 * * *$ \\
\hline & (6.8841) & $(12.6385)$ & $(8.2441)$ & $(8.5055)$ & $(7.7070)$ \\
\hline No. of observations & 455 & 79 & 376 & 56 & 399 \\
\hline$F$-Statistic & $63.29 * * *$ & $10.42 * * *$ & $29.15 * * *$ & $14.08 * * *$ & $81.16^{* * * *}$ \\
\hline$R^{2}(\%)$ & $77.99 \%$ & $79.95 \%$ & $53.37 \%$ & $73.59 \%$ & $78.23 \%$ \\
\hline
\end{tabular}

*** Significance at the $1 \%$ level $(\mathrm{p}<0.01)$

$* *$ Significance at the $5 \%$ level $(\mathrm{p}<0.05)$

* Significance at the $10 \%$ level $(\mathrm{p}<0.10)$ 
Table 7. Regression results of probit estimates

The table reports the coefficients and standard errors in the parentheses. All probit estimations are computed using White's corrected heteroscedasticity robust regressions.

\begin{tabular}{|c|c|c|c|c|c|}
\hline \multicolumn{6}{|c|}{ Dependent variable: $\mathrm{E}^{-\mathrm{CODE}_{i, k, t}}$} \\
\hline \multirow[t]{2}{*}{ Estimation method: } & Probit & Probit & Probit & Probit & Probit \\
\hline & $\begin{array}{c}\text { Full sample } \\
\text { (1) }\end{array}$ & $\begin{array}{c}\text { Non-South Africa } \\
\text { (2) }\end{array}$ & $\begin{array}{c}\text { South Africa } \\
\text { (3) }\end{array}$ & $\begin{array}{c}\text { Middle East } \\
\text { (4) }\end{array}$ & $\begin{array}{l}\text { Africa } \\
(5)\end{array}$ \\
\hline \multicolumn{6}{|l|}{ Independent variables } \\
\hline \multicolumn{6}{|l|}{ Test variables } \\
\hline \multirow{2}{*}{$\mathrm{G}-\mathrm{SCORE}_{i, k, t}$} & $0.064 * * *$ & $0.075 * * *$ & $0.062 * * *$ & $0.059 * * *$ & $0.060 * * *$ \\
\hline & $(0.0123)$ & $(0.0208)$ & $(0.0142)$ & $(0.0137)$ & $(0.0144)$ \\
\hline \multirow{2}{*}{ FEMDIR $_{i, k, t}$} & $0.034 * * *$ & $0.032 * *$ & $0.015^{* *}$ & $0.027 * *$ & $0.033 * * *$ \\
\hline & $(0.0072)$ & $(0.0156)$ & $(0.0076)$ & $(0.0129)$ & $(0.0074)$ \\
\hline \multirow{2}{*}{ BSIZE $_{i, k, t}$} & 0.039 & 0.074 & $0.033 * *$ & 0.050 & 0.027 \\
\hline & $(0.0908)$ & $(0.0605)$ & $(0.0142)$ & $(0.0963)$ & $(0.0347)$ \\
\hline \multirow{2}{*}{$\mathrm{BINDEP}_{i, k, t}$} & $-0.020 * * *$ & $-0.015 * * *$ & $-0.021 * * *$ & $-0.026^{* * *}$ & $-0.029 * * *$ \\
\hline & $(0.0048)$ & $(0.0052)$ & $(0.0059)$ & $(0.0091)$ & $(0.0063)$ \\
\hline \multirow{2}{*}{ DUAL $_{i, k, t}$} & $0.109 * * *$ & $0.022 *$ & 0.164 & $0.035^{*}$ & 0.137 \\
\hline & $(0.0332)$ & $(0.0124)$ & $(0.1576)$ & $(0.0187)$ & $(0.0958)$ \\
\hline \multirow{2}{*}{$\operatorname{AUDIT}_{i, k, t}$} & 0.555 & $0.299 *$ & 0.065 & $0.161 * *$ & $0.246^{*}$ \\
\hline & $(0.7024)$ & $(0.1631)$ & $(0.0996)$ & $(0.0722)$ & $(0.1447)$ \\
\hline \multicolumn{6}{|l|}{ Control variables } \\
\hline \multirow{2}{*}{$\operatorname{INSIDER}_{i, k, t}$} & -0.042 & -0.131 & $-0.101 * * *$ & -0.056 & $-0.118 * * *$ \\
\hline & $(0.0293)$ & $(0.0816)$ & $(0.0298)$ & $(0.0589)$ & $(0.0347)$ \\
\hline \multirow{2}{*}{$\mathrm{INST}_{i, k, t}$} & $-0.005^{* *}$ & $-0.014 * *$ & -0.008 & $-0.152 * *$ & -0.002 \\
\hline & $(0.0025)$ & $(0.0067)$ & $(0.0333)$ & $(0.0681)$ & $(0.0032)$ \\
\hline \multirow{2}{*}{$\mathrm{ROA}_{i, k, t}$} & $-0.012 * *$ & $-0.022 * *$ & $-0.019 * * *$ & $-0.010 * *$ & $-0.011 * *$ \\
\hline & $(0.0061)$ & $(0.0087)$ & $(0.0054)$ & $(0.0047)$ & $(0.0056)$ \\
\hline \multirow{2}{*}{$\operatorname{DEBT}_{i, k, t}$} & $-0.027 * * *$ & $-0.021 * *$ & $-0.023 * * *$ & $-0.038 * * *$ & $-0.024 * * *$ \\
\hline & $(0.0063)$ & $(0.0098)$ & $(0.0069)$ & $(0.0116)$ & $(0.0070)$ \\
\hline \multirow{2}{*}{$\mathrm{GROW}_{i, k, t}$} & 0.077 & 0.311 & 0.042 & 0.123 & 0.194 \\
\hline & $(0.0733)$ & $(0.1911)$ & $(0.0719)$ & $(0.1108)$ & $(0.1527)$ \\
\hline \multirow{2}{*}{ FSIZE $_{i, k, t}$} & $0.145^{* *}$ & $0.525 * * *$ & $0.244 * *$ & $0.644 * *$ & $0.347 * * *$ \\
\hline & $(0.0656)$ & $(0.1172)$ & $(0.0987)$ & $(0.3232)$ & $(0.1329)$ \\
\hline \multirow{2}{*}{$\mathrm{AGE}_{i, k, t}$} & $0.242 * * *$ & $0.155^{* *}$ & $0.267 * * *$ & $0.161^{*}$ & $0.201 * *$ \\
\hline & $(0.0936)$ & $(0.0728)$ & $(0.0927)$ & $(0.0931)$ & $(0.0971)$ \\
\hline COUNTRY & Yes & Yes & - & Yes & Yes \\
\hline INDSUTRY & Yes & Yes & Yes & Yes & Yes \\
\hline YEAR & Yes & Yes & Yes & Yes & Yes \\
\hline \multirow[t]{2}{*}{ Constant } & $-4.082 * * *$ & $-7.181 * * *$ & $-5.453 * * *$ & $-10.009 * * *$ & $-4.263 * * *$ \\
\hline & $(0.8897)$ & $(1.5194)$ & $(1.0263)$ & $(2.4437)$ & $(1.0301)$ \\
\hline No. of observations & 587 & 112 & 475 & 78 & 509 \\
\hline Wald $\chi^{2}$ & $85.20 * * *$ & $36.94 * * *$ & $68.79 * * *$ & $21.89 * * *$ & $93.87 * * *$ \\
\hline Pseudo $R^{2}(\%)$ & $34.09 \%$ & $40.38 \%$ & $32.69 \%$ & $39.18 \%$ & $36.05 \%$ \\
\hline
\end{tabular}

*** Significance at the $1 \%$ level $(\mathrm{p}<0.01)$

** Significance at the $5 \%$ level $(\mathrm{p}<0.05)$

* Significance at the $10 \%$ level $(\mathrm{p}<0.10)$ 